\title{
Fabrication and Optimization of Nanocatalyst for Biodiesel Production: An Overview
}

\author{
Sayfa Bano, Adil Shafi Ganie, Saima Sultana, Suhail Sabir and Mohammad Zain Khan* \\ Environmental Research Laboratory, Department of Chemistry, Aligarh Muslim University, Uttar Pradesh, India
}

\section{OPEN ACCESS}

Edited by:

$\mathrm{Hu} \mathrm{Li}$,

Guizhou University, China

Reviewed by:

Mofijur Rahman,

University of Technology Sydney,

Australia

Ao Xia,

Chongqing University, China

Heng Zhang,

Guizhou University, China

Hu Pan,

Jiaxing University, China

*Correspondence:

Mohammad Zain Khan

zn.khan1@gmail.com

Specialty section:

This article was submitted to

Bioenergy and Biofuels,

a section of the journal

Frontiers in Energy Research

Received: 01 July 2020 Accepted: 16 November 2020

Published: 17 December 2020

Citation:

Bano S, Ganie AS, Sultana S, Sabir S and Khan MZ (2020) Fabrication and Optimization of Nanocatalyst for

Biodiesel Production: An Overview. Front. Energy Res. 8:579014. doi: 10.3389/fenrg.2020.579014
Necessity and exploitation of fossil fuel products are implacable in serving the needs of humanity despite being a finite and limited resource. To meet the thrust of energy, biofuels derived from varieties of renewable resources are imperative in fulfilling the demand of renewable fuels on a large scale without creating environmental concerns. Biofuels are inevitably the result of the carbon fixation process which stores chemical energy, ultimately reducing the total amount of carbon dioxide. Different kinds of biofuels like bioethanol, biomethanol, biogas, and biodiesel are derived depending on varieties of feedstock materials. Among these, production of biodiesel augments the progression of clean and renewable fuel. In this review, we have discussed the production of biodiesel derived from various feedstock and using several processes like pyrolysis, direct blending, micro-emulsion, and trans-esterification, with critical discussion focussing on increasing biodiesel production using nanocatalysts. Biodiesel production mainly proceeds through homogenous and heterogeneous catalysis via trans-esterification method. The review further discusses the significance of nanocatalyst in heterogeneous catalysis based trans-esterification for large scale biodiesel production. With the advent of nanotechnology, designing and modification of nanocatalyst gives rise to attractive properties such as increased surface area, high thermal stability, and enhanced catalytic activity. The role of nanocatalysts have been extensively studied and investigated in regard to the increased biodiesel production. Along with the modification of nanocatalysts, we have briefly discussed the physico-chemical properties and the role of the optimization parameters as it plays a pivotal role in enhancing the biodiesel production commercially.

Keywords: biofuels, biodiesel, nanocatalyst, response surface methodology (RSM), trans-esterification reaction

\section{INTRODUCTION}

Since early human history, wood has been a major source of energy. With increasing time, there has been an ultimate shift to fossil fuels, which accounts for the majority of energy production (Le Quynh et al., 2017; Youse et al., 2019). Incessant globalization and industrialization has led to spike in the utilization of fossil fuel products like petroleum and coal (Touqeer et al., 2020). As global energy consumption is mainly dependent on the endangered and depleting fossil fuel reservoirs, the need for renewable energy or fuel sources is growing due to the ever-increasing demand. The demand for global energy by 2020 was estimated to be around 15 million tons of oil equivalent. Increasing energy consumption substantially demands higher energy, but the finite supply end will eventually delimit 
the depleting fossil fuel reservoirs. With the significant increase in global energy demand, developing renewable energy sources on a large scale plays an extensive role in overcoming the continuously growing need and demand (Martchamadol and Kumar, 2012).

To overcome this serious issue, there is an urgent need to develop or alleviate an alternate renewable energy source which poses as a clean fuel. Renewable sources contribute only around $20 \%$ to the global energy demand, while the remaining $80 \%$ is fulfilled by fossil fuels (Veronica Winoto, 2019). With the advancement in technology, various innovative ideas can uplift renewable energy technologies to new heights and provide sustainable ways to fulfil the increasing demand along with a clean environment (Azyan et al., 2018). The majority of the renewable sources like wind, solar, hydel and biofuels do not correspond to the estimated energy requirements. Among these, biofuel production currently serves as a new contributor in order to meet the growing energy demand. It mainly emphasizes biomass conversion to liquid fuels like bioethanol, biodiesel and biogases.

Among these, biodiesel as a potential fuel is developing at a faster rate, thereby controlling and plummeting the use of fossil fuels and other non-renewable resources (Prokopowicz et al., 2015). It is mainly focussed on biomass conversion to liquid fuels. To date, biomass has not been extensively used as reliable energy source in comparison to fossil fuels (Le et al., 2017). Identifying biomass feedstock as a raw material is an important task, as it is easily affected by factors such as moisture content and pretreatment processes. Due to the low energy density of biomass, it is also inconvenient in handling, transportation and storage conditions, setting a major drawback in large scale biodiesel production (Nizami and Rehan, 2018). Currently, enormous amounts of research on increasing biodiesel production have attained large public interest corresponding to huge hikes in oil prices, the necessity of increased energy security and concern regarding emissions of harmful greenhouse gas from fossil fuels (Balat, 2011).

Biodiesel production will eventually present the best solution over other conventional fuels. Biodiesel, a liquid fuel comprising of long chain fatty acid esters derived from vegetable oils, animal fats, micro and macro algal oil. Biodiesel production using nanocatalysts is one of the promising and advanced approaches for carrying out the process on a large scale (Talebian-kiakalaieh et al., 2013). Its physico-chemical properties can be easily varied by using a nanocatalyst, which produces different compositions of fatty acids methyl esters (FAME). Fatty acids methyl esters FAME composition includes saturated and unsaturated fatty acids, palmitic acid, myristic acid, and oleic acid. These methyl esters composition primarily govern the parameters like density, viscosity, cetane number and acid value which eventually affect the quality and quantity of biodiesel (Chozhavendhan et al., 2020).

Conventionally, biodiesel is produced by using homogenous and heterogeneous catalysis. As heterogeneous catalysts have various advantages of recyclability and reusability, basic catalyst is predominantly used in trans-esterification process of biodiesel production. However, these solid catalysts require more quantity and provide less surface area, thus reducing the overall activity of the catalyst (Borah et al., 2019). With the advent of nanotechnology, nanocatalysts play a prominent role in improving the yield and production quality of biodiesel along with the reduction in reaction time. Involvement of a nanocatalyst also leads to reduction in reaction temperatures, catalyst weight and alcohol to oil ratio. Ibrahim et al. (2020) have reported the role and amount of the nanocatalyst in biodiesel production. It was found that nanocatalysts play a prominent role in increasing the rate of reaction without being self-deteriorated. It also significantly lowers the activation energy of the reaction profiles. Additionally, the amount of nanocatalyst is also a critical parameter in determining the yield of biodiesel production (Ibrahim et al., 2020). Another researcher has also investigated the role of nanocatalysts especially in biodiesel production. It was observed that with zero catalyst loading under given reaction conditions, no biodiesel production was found, hence the presence and amount of nanocatalysts are vital for production of biodiesel (Anbessie et al.,2019).

Vast development in designing and fabrication of nanocatalyst contributes to many areas ranging from different kind of metal oxides (mixed metal oxides, alloys), hydrocalcite based catalyst, zeolite and other carbonaceous material based nanocatalysts (Talebian-kiakalaieh et al., 2013). These highly developed catalysts mainly possess excellent properties in withstanding the reaction conditions and also provide a large surface area to volume ratio. Assembling of different types of nanocatalysts also plays an important role depending on the nature and conditions of catalytic reactions, which in turn vary to a greater extent under different operating environments. It also evidently acts as an interface between homogenous and heterogeneous catalysis while monitoring its size at atomic level which eventually increases surface area as compared to solid acid/base based catalyst (Zuliani et al., 2018; Pan et al., 2019). By modulating the nanomaterial's surface, properties like catalyst active site, acidity or basicity and porosity can be greatly enhanced. Apart from this, morphology of the nanocatalyst can be extensively studied by varying reaction conditions of the synthesis. Various morphology such as nanocrystals, nanosponges, and nanocubes, expose different active sites with rough and mesoporous structure, thus overall increasing the surface area and reactivity (Fawaz et al., 2019). These highly developed nanocatalysts will eventually increase the production of biodiesel. Surface functionalization is prominent in increasing the overall acidity of nanocatalysts, eventually enhancing the catalytic activity, and introducing magnetic nanomaterials will help in easy separation recoverability and reusability (Gardy et al., 2017; Gardy et al., 2018).

Besides development in nanocatalyst areas, physico-chemical properties of biodiesel are also essential in estimating the quality and quantity of production for biodiesel. It is mainly dependent on the type of feedstock and pre-treatment process it undergoes (Hassan and Hossein, 2019). The pre-treatment process is quite a significant figure in controlling moisture content, estimation of free fatty acids, and final biodiesel products, etc. It will also improve the storage and transportation of the biodiesel keeping its stability intact (Amirthavalli and Warrier 2019). Biodiesel production is also dependent on the optimization parameters of the reaction conditions like methanol to oil molar ratio, catalyst 
amount, reaction temperature, and reaction time based on a few newly developed types of software like MINITAB and Response Surface Methodology (RSM). The optimized parameters are largely responsible for an increase in biodiesel production and can be easily operated on a large scale (Alaei et al., 2018).

This review presents a brief discussion on different types of biofuels with special focus on biodiesel production and its methodology. Herein, critical discussion emphasizes recent developments in the field of nanocatalysts in the production of biodiesel using heterogeneous catalysis via trans-esterification reaction. Different types of nanocatalyst and their effect on production have also been mentioned. Along with this, various physico-chemical properties and optimization parameters involved in biodiesel production have been significantly elaborated for increasing its production on industrial scale.

\section{BIOFUELS: A SUSTAINABLE ENERGY SOURCE}

Biofuels are the end products of a biological fixation process, mainly derived from renewable resources like wood, cellulosic and lignocellulosic material, edible and non-edible products, producing different kinds of biofuels like biohydrogen, bioethanol, biomethanol and biodiesel (Kushwaha et al., 2018 Khan et al., 2018;). Preceding through generation and covering the basic need in the energy sector via fossil fuels, biofuels on a large scale can minimize pollution and also reduce the depletion of ozone layer.

Biofuel production encompasses three categories based on its source of production. First and second generation fuels were produced from edible and starch based feedstock which is inefficient in terms of large production and price hike, as it poses certain disadvantages of being an energy intensive source, a time consuming task, and causing the release of harmful gases. However, third generation biofuels are mainly derived from effective feedstock sources and developed catalytic conversion processes. It mainly relies on the utilization of non-edible, lignocellulosic, and microalgae-based feedstock (Rai et al., 2016; Thangaraj et al., 2019). Figure 1 briefly illustrates the stages in the production of biofuels.

Biofuels are mainly categorized into biogas, bioethanol, and biodiesel. Biogas production is aided with the help of anaerobic digestion (AD) using sewage sludge, agricultural waste, and other products. Increased biogas production can be attained under optimized conditions with the help of a nanocatalyst (Kovács et al., 2013; Deepanraj and Senthilkumar, 2020). It mainly includes biomethane, biohydrogen and carbon dioxide. They are produced either from pyrolysis or gasification process involving renewable resources followed by its conversion to gases like methane, ammonia, and hydrogen sulphide etc. under anaerobic conditions (Kana et al., 2012). Various other gases are also produced which can be further used in different synthesis processes (Li et al., 2020; Senés-Guerrero et al., 2019). In comparison to their bulk counterparts, nanomaterials with excellent structural and morphological properties significantly enhance the methane production. Large quantities of biomethane can be used as a fuel directly as it resembles properties of natural gas, or it can also be converted to electricity via fuel cell technology (Deepanraj et al., 2016; Deepanraj and Senthilkumar, 2020). However, it cannot be commercially used
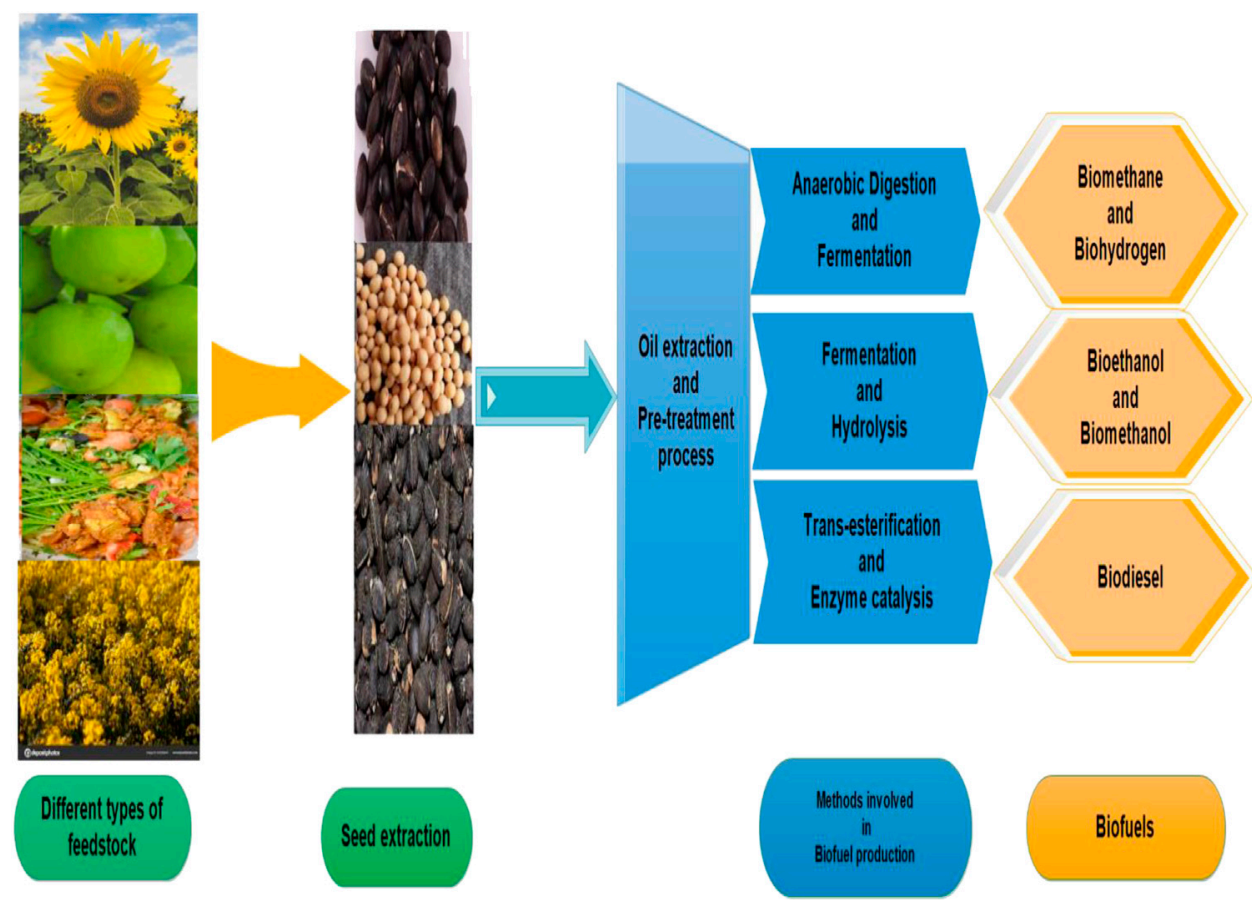

FIGURE 1 | Different stages of biofuel production 


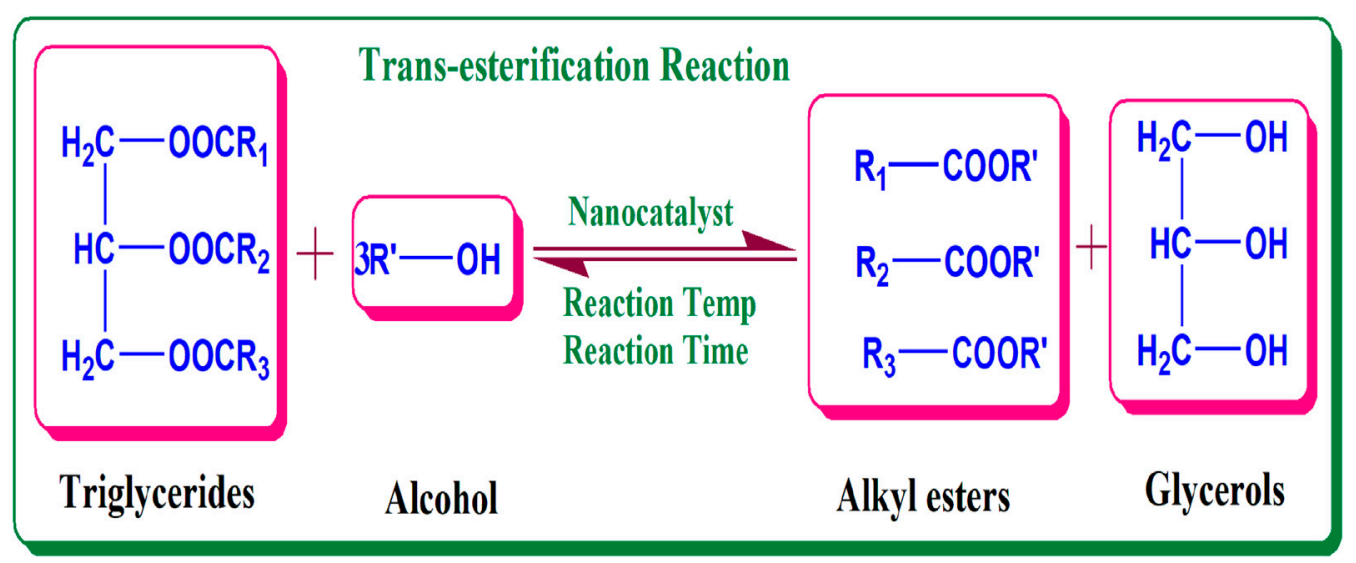

FIGURE 2 | Reaction involved in biodiesel production via trans-esterification method (Anbessie et al., 2019).

as a fuel because of certain limitations regarding storage and transportation.

Biomethanol and bioethanol are alcoholic products derived from either enzymatic conversion of starch and sugar as feedstock materials or chemical conversion of lignocellulosic material as feedstock, which undergoes various pre-treatment processes followed by hydrolysis of 5/6 carbon sugars, and further distilled to produce fuel grade ethanol (Shalaby, 2013; Chen and Fu, 2016; Kushwaha et al., 2018). Bioethanol is used on a large scale as compared to biomethanol because of various advantages like its non-corrosive nature, cost efficientness and lower energy requirements (Khan et al., 2019). It was also reported that USA and Brazil are the largest consumers of bioethanol as an energy source over conventional fuel because of its low emissions of harmful gases, low production cost, and feasible availability of feedstock materials (Shalaby, 2013). It can easily replace gasoline so as to avoid $\mathrm{CO}_{2}, \mathrm{NO}, \mathrm{CO}$, and other harmful gas emissions.

Biodiesel, as a potential clean fuel, is mainly produced by trans-esterification of vegetable oils using methanol and a nanocatalyst. Chemically, it is fatty acid alkyl esters produced from trans-esterification of triglycerides with methanol as an alcohol source producing esters of fatty acids and glycerol (Anbessie et al., 2019). Figure 2 encodes the reaction involved in the production of biodiesel.

The produced biodiesel mainly consists of different types of fatty acids depending on its composition. It is highly renewable, non-toxic and biodegradable with low sulphur content and reduced harmful gas emissions. It is an environmentally benign fuel mitigating the detrimental effects of fossil fuels. They can also be used as a blend with diesel fuel, thereby reducing the amount of pollutants and harmful gases released from conventional fuels as biodiesel is mainly derived from transesterification of oils at a given operating condition.

\section{Feedstock and Technique for Biomass Conversion to Biodiesel}

Feedstock mainly consists of oils and fats majorly derived from plants and animals. These feedstock materials are mainly biodegradable and non-toxic materials for their utilization in trans-esterification process. Choosing a good raw material is a first and basic criterion in biodiesel production. Plant derived feedstock is mainly categorised into edible and non-edible oil. The production and cultivation of feedstock is mainly dependent on geographical conditions of the given area. For biogas and bioethanol production, animal and plant waste products, organic waste materials, starch, cellulosic, and lignocellulosic are widely investigated, as biodiesel production was largely derived from edible oils like safflower, palm oil, sunflower, and coconut oil etc. However, it posed serious issues of food security and increasing consumption leading to high cost thus, reducing its utilization on a large scale.

However, non-edible feedstock has become a great rescue in this regard, as it can be cultivated on a large scale. It mainly includes jatropa, jojoba, neem, rubber seed tree, and tobacco seed, etc. The most studied feedstock materials are Jojoba (El-seesy et al., 2016) and Jatropa (Chavan et al., 2015). Jojoba is a shrub belonging to the Simmondsiaceace family, producing $45-55 \%$ of fatty acids while Jatropa majorly contributes due to rapid growth and high seed productivity. It is profoundly grown in tropical and sub-tropical regions of the world, and is also an easily cultivated plant with a maximum amount of fatty acid content. Besides plants, animal fats and waste cooking oil can also be a promising and economical feedstock in biodiesel production (Behzadi and Farid, 2007). These waste cooking oils containing free fatty acids are ultimately reduced by using pre-treatment processes and alkali based trans-esterification process as high fatty acid content leads to soap formation. However, the pre-treatment process is mainly affected by various reaction parameters (Faisal et al., 2018). Biodiesel production mainly occurs by esterification and trans-esterification of free fatty acids and triglycerides, as the amount of free fatty acid corresponds to its yield.

An important class of bacteria, algae, fungi (Azhar et al., 2017) and microbes can also be used in biodiesel production. They consist of both photosynthetic and non-photosynthetic micro-organisms, mainly derived from stagnant ponds (Zhang et al., 2013). They create a new platform for the generation of oils used in biodiesel production with various advantages of easy production, highly rich 
TABLE 1 | Different types of feedstock used in biodiesel production.

\begin{tabular}{|c|c|c|}
\hline Edible feedstock & Non-edible feedstock & Algae based feedstock \\
\hline Safflower & Jatropa & Cyanobacteria \\
\hline Sunflower & Babassu & Microalgae oil \\
\hline Coconut & Tallow & Microbes \\
\hline Palm oil & Jojoba & Red algae \\
\hline Rice bran & Rapeseed & Diatoms \\
\hline Canola & Karanja oil & Brown algae \\
\hline Corn & Tobacco & \\
\hline Wheat & Neem & \\
\hline Barley & Rubber seed & \\
\hline \multirow[t]{4}{*}{ Soybean } & Waste cooking oil & \\
\hline & Animal fats & \\
\hline & Mahua & \\
\hline & Salmon oil & \\
\hline Shalaby (2013); Zahan and Kano (2018); Singh and Gaurav (2018); Thangaraj et al. (2019) & Shuit et al. (2015); Anbessie et al. (2019) & Hossain et al. (2019a) \\
\hline
\end{tabular}

in oil content, no release of $\mathrm{CO}_{2}$, self-generating, highly feasible, and cheap. They mostly include cyanobacteria, microalgae, and microbes (Hossain et al., 2019a). Table 1 presents various types of feedstock, and an evaluation of these wide feedstock will eventually increase biodiesel production on a large scale, mitigating the use of previous materials.

Biomass conversion of the feedstock is mainly based on techniques such as thermal treatment, pyrolysis, and gasification, etc. Conversion of biomass to biodiesel generally proceeds via many processes like thermochemical and biological processes. The thermochemical process is the most significant route in biomass conversion as it further extends to various categories depending on the type of feedstock used. It is mainly divided into different routes like pyrolysis, liquefaction, and gasification. They mainly produce syn gas, tar, and oil which can be utilised for further application regarding various fuel production. In biodiesel production, oil extraction is a major step, which can also be extracted from enzyme extraction, mechanical extractor, and solvent extraction method depending on the nature of feedstock (Achten et al., 2008; Akia et al., 2014; Mishra and Goswami, 2017). Oil extraction is very important in quantifying the production of biodiesel, as it mainly contributes to the nature of fatty acids methyl esters content which majorly affects the physico-chemical properties of the final products.

Recent technological advances may correspond to production of biofuels such as biohydrogen biomethane and by carbon dioxide reduction via chemical and electrochemical techniques. They mainly produce methane and hydrogen under anaerobic conditions by using bacteria as feedstock material. Different species of bacteria can be cultured depending on its growth conditions certainly increasing the quantity of biogas production which ultimately can be converted into either electricity or in $\mathrm{C} 1$ derived fuel which can be used as biodiesel fuel (Anwer et al., 2019).

\section{Types of Catalysis Involved in Biodiesel Production}

Since the production of biodiesel, various methods like direct blending, pyrolysis, micro-emulsification and trans-esterification have been implemented. All the methods are feasible to a certain extent along with some advantages and disadvantages as elaborated in Table 3. Biodiesel synthesis proceeding through direct blending, pyrolysis, and micro-emulsification methods are insufficient for large scale production. Among these techniques trans-esterification is the best technique which proceeds via catalytic reaction involving fatty acids and methanol in the presence of a catalyst, has evolved with various advantages like increased production, easy separation, and limitation of mass transfer resistance.

It is further divided into homogenous and heterogeneous catalysis. Homogenous catalysis proceeds through acid and base catalyzed reaction. Base catalyzed reaction is much faster than acid catalyzed reaction giving maximum yield. The most commonly used catalysts are $\mathrm{NaOH}, \mathrm{KOH}, \mathrm{NaOCH}_{3}$, and $\mathrm{KOCH}_{3}$ (Gardy et al., 2017; Silveira et al., 2019), operating under mild temperatures giving maximum yields (Gardy et al., $2019 b$ ). It also requires high-grade feedstock oil to minimize the saponification reaction making the process more cost consumptive. While acid catalyzed reactions require high temperature and longer reaction times. It is also proven that triglycerides conversion was maximally achieved by homogenous catalysis owing to good catalytic activity and high reaction rate (Ibrahim et al., 2020). However, it shows serious issues related to separation and purification of catalyst and product. The more often catalysts are consumed, they generate heavy amounts of wastewater and cause equipment corrosion (Gardy et al., 2019). To overcome the significant shortcomings of homogenous catalysis, heterogeneous catalysis is widely investigated in trans-esterification reaction. It is much more efficient and can be easily recycled depending on the nature catalyst. Heterogeneous catalysis is further sub-divided on the basis of type of catalyst used like alkali-, acid-, and enzyme-based transesterification process (Marwaha et al., 2018). It mainly depends on the type of metal, metal oxides, acids, bases, hydrocalcites and zeolites supported by the nanocatalyst being used. Table 4 summarizes the research findings in context of the role of catalysis involved in biodiesel production.

Unlike homogenous catalysis, heterogenous catalysis can significantly convert low grade feedstock oil and fats using a 
solid acid catalyst. Solid acid and base catalyzed reactions eventually increase the catalytic efficiency and undergo both esterification and trans-esterification reactions simultaneously under extreme reaction conditions. It has shown much tolerance over high free fatty acids content and water. Recent development on synthesizing solid acid and base catalysts with mono-functionality or bi-functionality will eventually enhance the catalytic activity and the reaction conditions will be improved. Extensive research has been developed on synthesizing the novel solid acid catalyst by using organic polymer and imidazole salt based bi-functional catalysts which worked significantly under milder reaction conditions as compared to previous reported literature (Pan et al., 2020). Pan et al. have reported the synthesis of an imidazole salt-based catalyst, namely 1,3-disulfonic acid imidazolium tetrachloroferrate ([DSI $]\left[\mathrm{FeCl}_{4}\right]$ ) bi-functional catalyst possessing Lewis (L)acid and Brønsted (B) acidic properties. The developed catalyst has shown excellent catalytic activity in the conversion of FPLF oil to biodiesel with a conversion efficiency of $97 \%$. Owing to its bifunctionality the number of acidic active sites were increased significantly with mesoporous morphology which in turn helps in increasing the overall production of biodiesel from FPLF oil. The catalyst has high acidic properties with a $\mathrm{B} / \mathrm{L}$ molar ratio of 2.12 revealing that the active sites are mainly the representation of cation and anion respectively in comparison to commercially available resins which overall increases the catalytic activity. The role of the catalyst was briefly analyzed in the presence and absence of the catalyst. In the absence of the catalyst the reaction barely proceeds, while taking $\mathrm{FeCl}_{3}$ as a homogenous catalyst, biodiesel production of $63.2 \%$ was obtained, and using [DSI] [Cl] as catalyst, $86.0 \%$ of biodiesel was reported. As these catalysts serve as homogenous catalysts, this mainly brings the problematic issues of catalyst separation and reusability. However, when the reaction was done using $[\mathrm{DSI}]\left[\mathrm{FeCl}_{4}\right]$ as a solid acid heterogeneous catalyst, the corresponding biodiesel production of $97.0 \%$ was achieved under mild reaction conditions which is due to the presence of BA and LA character. The catalyst heterogeneity was also confirmed from FT-IR spectra representing the intact acidic and basic active sites. The catalyst was also reused for four runs with the yields of $95 \%$ (Pan et al., 2018).

Another study reported on synthesizing heterogeneous solid acid catalysts using ionic liquids functionalized with melamineformaldehyde polymer. The catalyst has been used for biodiesel production from oleic acid under mild reaction conditions. These catalysts showed a mesoporous and coral-like structure with a rough surface, indicating the combination of amorphous covalent-organic polymers basically imparting excellent structural and thermal stability. The catalyst possessed a surface area of $283.0 \mathrm{~m}^{2} / \mathrm{g}$ with a corresponding porosity of 0.65-0.99 obtained from the hysteresis loop, confirming its structural integrity with thermal stability up to $300^{\circ} \mathrm{C}$. This study also depicted the role of the catalyst in biodiesel production, as mentioned, the absence of catalyst produces low yield, while varying catalyst amount from 1 to $4 \mathrm{wt} \%$, the biodiesel yield increases from 57 to $95 \%$. The increase in production is mainly because of the presence of large acidic 


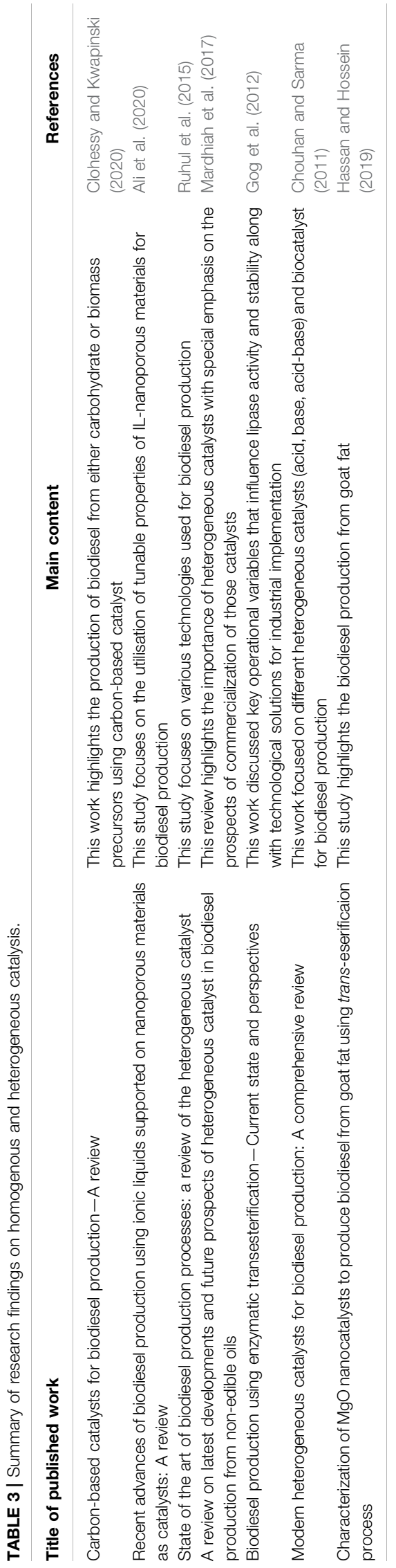

active sites and the large surface area of the catalyst which increases the overall catalytic activity. The catalyst has also been evaluated for reusability tests with a production efficiency of $88 \%$ for four runs (Pan et al., 2019). The newly developed catalyst can be efficiently and robustly used in biodiesel production.

Solid base catalysts are also deemed to have high conversion efficiency along with easy separation and recyclability. Synthesizing solid base catalysts from natural resources will be efficient in cheap biodiesel production. Dai et al. reported the synthesis of $\mathrm{Si}$ and $\mathrm{Al}$ doped lithium carbonate compound derived from clay materials using one-pot blending and grinding followed by heating at a high temperature. The optimum doping and calcination temperature significantly increase the number of active basic sites thus increasing the catalytic activity. Beyond optimum calcination temperature, the surface morphology reveals high agglomeration, further decreasing the pore size and diameter. The catalyst was utilized for biodiesel production using soybean oil at optimum reaction parameters (reaction temp. $-65^{\circ} \mathrm{C}$, reaction time $-4 \mathrm{~h}$, methanol to oil molar ratio-36:1 and catalyst weight-8 wt\%) producing a yield of $98-99 \%$. The catalyst was however recycled for a seventh run with an insignificant loss of activity (Dai et al., 2020). Roy et al. discussed another solid base catalyst $\mathrm{BaSnO}_{3}$ as single-phase perovskite. The base catalyst of different $\mathrm{Ba}: \mathrm{Sn}$ ratios at varying calcination temperatures was synthesized by the impregnation method. The $\mathrm{Ba}: \mathrm{Sn}$ ratio of $1: 1$ and calcination temperature of $850^{\circ} \mathrm{C}$ was used for transesterification of waste cooking oil for biodiesel production. The optimized $\mathrm{BaSnO}_{3}$ was found to be highly active with a large surface area and pore diameter of $144.09 \mathrm{~m}^{2} / \mathrm{g}$ and $28.34 \mathrm{~nm}$ respectively. The average pore size distribution mainly corresponds to a mesoporous range. The optimum reaction conditions like catalyst weight $-2.5 \mathrm{wt} \%$, reaction temperature and time, $-65^{\circ} \mathrm{C}$ and $25 \mathrm{~min}$ respectively, and a methanol to oil molar ratio of $-16: 1$ produces a biodiesel yield of $98 \%$ and the recyclability of the catalyst for up to 5 cycles with total production of $81.6 \%$ (Roy et al, 2020; Sulaiman et al., 2019). However, it was observed that this solid base catalyst also uses extreme reaction conditions and a high alcohol to oil ratio. The extreme reaction conditions will delimit its large scale production and commercialization.

Furthermore, the presence of nanocatalysts in heterogeneous catalysis present a new pathway for synthesizing different nanocatalytic materials, which significantly enhanced the biodiesel production corresponding to its high catalytic activity, large surface area and high porosity. As a bulk metal oxide-based catalyst shows instability at high temperatures, which leads to catalyst deactivation along with the metal leaching and surface deformation creating major hindrance in increased biodiesel production. To overcome these serious drawbacks, recent extensive studies have been focused pertinently on developing a wide variety of nanocatalysts based on supported materials like zeolites, zirconia, polymers, and heteropolyacids catalysts, which significantly impart chemical and structural stability to sustain high reaction temperatures and longevity with increased catalytic activity (Zuliani et al., 2018). 
The enzyme catalyzed reactions are quite expensive and process under milder reaction conditions corresponding to less energy consumption with a simplified purification process. Low grade feedstock with high free fatty acid content can also be converted easily. Nanocatalysts immobilized over enzymes present a new perspective in the production of biodiesel. However, it still cannot be used on large scale due to factors like long reaction time, type of enzyme immobilized, operating conditions like $\mathrm{pH}$, and temperature (Mishra and Goswami, 2017; Sarno and Iuliano, 2019).

\section{APPLICATION OF NANOCATALYST FOR BIODIESEL PRODUCTION}

Nanocatalyst properties like catalytic activity, specificity and overall stability affect the cost of biodiesel production. Catalytic activity is affected by physical, mechanical, and thermal degradation. Numerous modifications of nanocatalysts are being designed, and it has been concluded that powdered acidic and basic catalysts are unsuitable for production on an industrial scale, owing to its small particle size of catalyst as it substantially affects catalytic activity and methyl ester yield (Azyan et al., 2018; Silveira et al., 2019). The structural and morphological nature of a catalyst plays a huge role in heterogeneous catalysis. Spherical catalysts have a good stability and are easy to separate from the reaction mixture. Designing nanocatalysts in order to have better stability over high temperatures is also a main parameter affecting the reaction conditions, as it also increases the chances of recyclability and reusability of the nanocatalyst (Rasouli and Esmaeili, 2019). Fabrication of nanocatalysts in the production of biodiesel has gained enormous interest in recent years. Various types of catalysts consisting of inorganic components such as oxides, sulphides, and metal salts as well as organic, including ion exchange resin and enzyme are being developed and the comparative study of different types of catalysts are mentioned in Figure 3. In light of nanotechnology, synthesizing the catalyst on a large scale would need to surpass many hurdles posed by the utilization of conventional catalysts (Deepalakshmi et al., 2015). The solid based catalyst also has serious problems of mass transfer resistance, time consumption, fast deactivation, and inefficiency of catalysts in long term use (Fattah et al., 2020). To overcome the limitations of solid based catalyst, nanocatalysts can be exploited to introduce lewis acidic or basic characters, increased acidity and active sites to the composites in order to improve its efficiency in catalysing the trans-esterification reaction. Nanocatalyst modification using different materials are of current interest as it significantly increases the surface area and porosity, reduces the leaching of metal ions, and increases the withstanding ability to acidic and environment thermal stability.

Many researchers have now focused on the development of nanocatalysts consisting of polymer, zeolite, and carbon-based nanomaterials, which mainly present attractive properties of high catalytic activity, reducing the reaction time and temperature. Thus, modification and synthesis of nanocatalysts will provide a significant increase in biofuel production (Marwaha et al., 2018).
The newly developed nanocatalyst can be synthesized by many possible methods like precipitation, impregnation, chemical vapour deposition (CVD), and electrochemical deposition techniques. However, precipitation and impregnation methods are cheap and cost effective, but they restrict a limitation on the regular size control and the overall morphology of the nanocatalyst. As CVD and electrochemical techniques produce a well-controlled morphology and size of the nanoparticles, they are rather expensive and require high temperatures. To overcome these challenges, we have discussed various kinds of nanocatalysts and their role in increasing biofuel production (Saoud, 2018).

\section{Metal Oxides-Based Nanocatalysts}

Metal oxide based solid catalysts are being conventionally used in biodiesel production. These catalysts play a very important role in homogenous catalysis and are largely responsible for the conversion of processed feedstock on a large scale. These correspond to major production of biodiesel. These catalysts pose certain limitations in the reduction of its activity as it cannot be separated after its use with increasing reaction time. Developing newly modified nanocatalysts based on oxides of various metals like $\mathrm{Ca}, \mathrm{Zn}, \mathrm{Mg}$ etc. plays a pivotal role in catalyzing the reaction along with an increase in production (Rengasamy et al., 2014; Thangaraj et al., 2019). Table 4 summarises the utilization of metal oxide based nanocatalysts for increasing biodiesel production.

As Bharti and Singh (2019) reported the synthesis of a calcium oxide nanocatalyst via the sol-gel method, and utilized it in the synthesis of biodiesel using soybean oil as feedstock material. The nanocatalyst has proven to be efficient and effective in terms of possessing increased active sites, high surface to volume ratio, with a small particle size of $8 \mathrm{~nm}$ in correspondance to nanoscale level/nanometric scale. The BET surface area and pore diameter were found to be $67.78 \mathrm{~m}^{2} / \mathrm{g}$ and $3.302 \mathrm{~nm}$ which is also high as compared to commercially available $\mathrm{CaO}$ catalysts. The increasing surface area is mainly due to small particle size, which correspondingly increases the reaction rate. After considering various optimization parameters like catalyst amount, methanol to oil ratio, and reaction temperature, a biodiesel production of $97.61 \%$ was obtained (Bharti and Singh, 2019). The $\mathrm{CaO}$ nanocatalyst can easily convert a maximum amount of fatty acids and oils, but it is unsuitable for long term use due to leaching and blockage of active sites. However, doping of metal and metal oxides can significantly reduce its inefficiency to a large extent.

Borah et al. (2019) also studied $\mathrm{Zn}$ doped egg-shell $\mathrm{CaO}$ nanocatalyst for trans-esterification of waste cooking oil used as feedstock. The nanocatalyst was synthesized using a wet impregnation method by varying $\mathrm{Zn}^{2+}$ concentration $(0.5-2 \mathrm{wt}$ $\%$ ) doped with $\mathrm{CaO}$. The nanocatalyst with $1 \mathrm{wt} \% \mathrm{Zn} / \mathrm{CaO}$ showed a spherical shaped morphology with non-uniform size having an average particle size of $30-42 \mathrm{~nm}$ thus creating more active sites and increased activity. However, with increasing $\mathrm{Zn}^{2+}$ concentration beyond, the catalytic activity of the nanocatalyst decreases while the spherical shape morphology also becomes distorted, thereby reducing the number of active sites as confirmed from SEM images. Besides this, the catalyst amount 
was concomitantly varied up to $5 \mathrm{wt} \%$ giving maximum biodiesel production. The nanocatalyst at the given operating conditions of $5 \mathrm{wt} \%$ catalyst amount, $20: 1$ molar ratio of methanol to oil at $65^{\circ} \mathrm{C}$ reaction temperature and 4 -h reaction time has provided maximum biodiesel production of $96.74 \%$. It was further reused for five runs, but the yield decreased gradually which may be because of catalyst poisoning and leaching of metal ions. The comparison of XRD spectra of fresh and reused catalysts also revealed the loss of crystallinity contributing to the decrease in overall catalytic activity (Borah et al., 2019).

Todorović et al. (2019) also reported the optimization of various reaction variables like methanol to oil ratio (7.1:1), catalyst concentration $(0.7 \mathrm{M})$, and reaction temperature of $52^{\circ} \mathrm{C}$ in biodiesel production using a $\mathrm{CaO}$ nanocatalyst and crude biodiesel as co-solvent with corresponding biodiesel yield of $99.8 \%$. The catalyst was reportedly used four times with varying reaction conditions giving a biodiesel conversion of $97.7 \%$ in $5 \mathrm{~h}$ at the second cycle (Todorović et al., 2019). Various researchers have also reported the synthesis and utilization of $\mathrm{CaO}$ and doped $\mathrm{CaO}$ nanoparticles as nanocatalysts because of large surface area to volume ratios, and high basicity which results in an increase in conversion of fatty acids to fatty acid methyl esters.

Rahman et al. demonstrated the synthesis of calcium oxide nanoparticles using waste chicken eggshells by a calcination method, further using a wet impregnation method, it was doped with $\mathrm{Zn}$ and $\mathrm{Cu}$ metal respectively. Biodiesel production using doped $\mathrm{CaO}$ nanocatalyst shows increased production under the given optimized reaction parameter of methanol to oil molar ratio $(6: 1)$, catalyst amount $(5 \mathrm{wt} \%)$ and reaction temperature and time of $65^{\circ} \mathrm{C}$ and $2.5 \mathrm{~h}$ respectively. Among these three nanocatalysts, $\mathrm{Zn} / \mathrm{CaO}$ have shown maximum efficiency in biodiesel production along with its reusability of up to seven consecutive cycles with an approximate corresponding yield of $85 \%$ (Rahman et al., 2018). As $\mathrm{CaO}$ nanocatalyst is a highly investigated basic catalyst in trans-esterification reaction, it also contributes negatively to the conversion efficiency because of leaching. Leaching is mainly caused by hydrolyzation of the catalyst and it ultimately results in saponification, thus reducing the overall catalytic activity and selectivity of the catalyst. Wen et al. has reported the development of $\mathrm{Li}$ doped $\mathrm{MgO}$ nanocatalyst at its dosage of $9 \%$, yielding $93.9 \%$ at a reaction temperature of $60^{\circ} \mathrm{C}$ using a molar ratio of methanol to oil of 12:1 (Wen et al., 2010). These catalysts provide more basic site formation due to the incorporation of $\mathrm{Li}$, thereby increasing the biofuel production. Xie et al. (2007b) has developed other nanocatalysts like $\mathrm{Na}$ doped $\mathrm{ZnO}$ and $\mathrm{Li}$ doped $\mathrm{ZnO}$, and utilized it in transesterification reaction showing good catalytic activity mainly corresponding to the amount of lithium loading (Xie et al., 2007b).

Regarding binary metal oxides, Mguni et al. (2012) reported sunflower oil being used as a feedstock material and nanocatalyst $\mathrm{MgO}$ deposited on $\mathrm{TiO}_{2}$ used as supporting material. The developed nanocatalyst has been used for the production of biodiesel by varying the catalyst concentration and reaction temperature. The $\mathrm{MgO}$ concentration of $10,20,30 \%$ weight have been loaded over $\mathrm{TiO}_{2}$ nanoparticles which has been utilized further for biodiesel production of $84,91,95 \%$ at temperature $250^{\circ} \mathrm{C}$, while 15,35 , and $42 \%$ at corresponding temperature of $150^{\circ} \mathrm{C}$ respectively indicating the effect of temperature. The effect of $\mathrm{MgO}$ loading increases the catalytic activity with limited loss of leaching and catalytic activity (Mguni et al., 2012).

Vahid and Haghighi (2016) reported the nanocatalyst $\mathrm{MgO} /$ $\mathrm{MgAl}_{2} \mathrm{O}_{4}$ based on spinel structure of magnesium, mainly synthesized from the combustion method followed by the impregnation method. The prepared catalyst possessed high surface area with excellent morphological properties and has been utilized for biodiesel production using sunflower oil as the feedstock. In this study, the effect of the fuel ratio was analyzed while synthesizing the catalyst. It was evident that the fuel ratio has a significant impact on morphology, pore size, pore diameter and specific surface area. The optimum fuel ratio of 1.5 has shown the specific surface area and average pore diameter of $60.6 \mathrm{~m}^{2} / \mathrm{g}$ and $6.3 \mathrm{~nm}$ respectively. With increasing fuel ratio, the crystallinity and surface area of the catalyst increases, indicating the complete conversion of the precursors into final products. The optimized catalyst was further tested for biodiesel production at operating reaction parameters (reaction temperature- $110^{\circ} \mathrm{C}$, reaction time- $3 \mathrm{~h}$, catalyst amount$3 \mathrm{wt} \%$ and M:O ratio-12:1) with a conversion efficiency of $95.7 \%$. The catalyst has been further analyzed for reusability tests with loss in catalytic efficiency of 5-9\% after the third run, which is due to leaching of active species $\mathrm{MgO}$, however after the third run there is insignificant loss in the activity of the catalyst (Vahid and Haghighi, 2016). As observed from the study, MgO doping also has a substantial impact on improving the biodiesel yield.

Apart from this, a $\mathrm{TiO}_{2}$ based nanocatalyst has also been extensively investigated with several modifications. Gardy et al. (2017) significantly discussed the modification of $\mathrm{TiO}_{2}$ based nanocatalysts in biodiesl production. A mesoporous $\mathrm{TiO}_{2} /$ $\mathrm{PrSO}_{3} \mathrm{H}$ solid acid nanocatalyst was developed by the grafting method. In this study propyl sulfonic acid was loaded for $\mathrm{TiO}_{2}$ support and was simultaneously used for the esterification and trans-esterification process for biodiesel production using used cooking oil as feedstock. FAME conversion of $98.3 \%$ was achieved. Increased conversion mainly corresponds to post functionalization over nanostructured material due to the hydrophilic sulphonic group which increases the acidic strength and active site of the nanocatalyst, providing more accessibility between feedstock oil and methanol. The nanocatalysts were recycled and reused for four runs without appreciable loss in catalytic activity (Gardy et al. (2017)).

Further novel modification of $\mathrm{TiO}_{2}$ nanoparticles (NPs) based on solid acid magnetic catalysts have been synthesized using the functionalization of $\mathrm{TiO}_{2} \mathrm{NPs}$. The $\mathrm{SO}_{4} / \mathrm{Fe}-\mathrm{Al}-\mathrm{TiO}_{2}$ catalyst uses alumina as buffer layer, while hematite was employed to impart the magnetic character. The buffer layer is used to prevent the setback, as magnetic material loses its activity under acidic conditions. Sandwiching the metal oxides with polymer and stable materials will improve the overall stability of the catalyst. Then sulfation was done using chlorosulphonic acid in order to impart Brønsted acidity. The novel catalyst was 
utilized in the trans-esterification of waste cooking oil with a conversion efficiency of $96 \%$. The catalytic activity was attributed to the incorporation of sulphate which provides significant acidity to the overall catalyst, while magnetic material will ease in the separation procedure with small amounts of loss during the recovery procedure. The catalysts were efficiently used for ten cycles without any loss in their activity. The catalyst was quite effective for simultaneous esterification and trans-esterification reaction and feedstock containing high (20 wt. \%) free fatty acids content. (Gardy et al., 2018). Ambat et al. reported the synthesis of $\mathrm{TiO}_{2}$ nanoparticle doped with potassium tartarate by the impregnation method and further utilized linseed oil for biodiesel production. The potassium tartarate doping significantly increases the basicity of the nanocatalyst, giving a maximum production of $98.9 \%$. The catalyst showed promising results up to five cycles without loss in its activity (Ambat et al., 2018b)

Various magnetite based nanocatalysts have been prepared and further utilized for trans-esterification of triglycerides for biodiesel production (Shi et al., 2017). Feyzi et al. (2013) studied the trans-esterification reaction of sunflower oil using the nanocatalyst $\mathrm{Cs} / \mathrm{Al} / \mathrm{Fe}_{3} \mathrm{O}_{4}$ under optimized reaction conditions, leading to $94.8 \%$ production of biodiesel while showing excellent catalytic activity. The present nanocatalyst reports the effect of different molar ratios of $\mathrm{Cs}-\mathrm{Al}$ and $\mathrm{Cs}-\mathrm{Fe}$ on the nanocatalyst, while calcination temperature and time have also been analyzed in order to maximize the overall performance of synthesized nanocatalyst. The magnetic nanocatalysts have shown excellent catalytic activity at an optimum calcination temperature and time of $500^{\circ} \mathrm{C}$ and $7 \mathrm{~h}$. From the given study it was confirmed that beyond optimum conditions the nanocatalyst shows morphological and textural differences owing to an agglomeration caused by sintering, the surface area has also been reduced as confirmed from BET surface area analysis. The nanocatalyst optimization followed by reaction parameters optimization presents a significant increase in biodiesel production (Feyzi et al., 2013).

Mixed metal oxides nanoparticles also impart a good interaction between free fatty acids and methanol, besides excellent tolerance at high temperatures giving enhanced production.

Future studies can be focused on analyzing the phase structure of $\mathrm{TiO}_{2}$ nanoparticles and other metal oxides while doping with polymeric and carbon based nanomaterials, to significantly improve the stability and catalytic activity of the nanocatalyst which correspondingly increases biodiesel yield.

\section{Carbon Based Nanocatalysts}

Nanocatalysts derived from carbon materials like graphene, carbon nanotubes (Gardy et al., 2019b), and reduced graphene oxides have shown good physical and chemical properties corresponding to different morphologies and sizes of the derived nanocomposite materials (Shu et al., 2019; Nizami and Rehan, 2018). Poonjarernsilp et al. has reported the use of multiwall porous nanohorn carbon nanotubes (CNT) dispersed in $\mathrm{Fe} / \mathrm{Fe}_{2} \mathrm{O}_{3}$ mixed nanoparticles for simultaneous determination of trans-esterification reaction (Poonjarernsilp et al., 2014). Guan et al. (2017) reported the trans-esterification of triglycerides using sulphonated multiwalled CNT as a nanocatalyst. Biodiesel production of $97.8 \%$ was obtained in $1 \mathrm{~h}$, at $150^{\circ} \mathrm{C}$, and with $3.7 \mathrm{wt} \%$ catalysts. It was revealed that nanocatalysts with acidic character, and high porosity and surface area leads to better catalytic activity of the nanocatalyst (Guan et al., 2017). Table 5 represents the use of carbon based nanocatalysts in enhanced biodiesel production.

As carbon nanotubes possess both chemical and structural stability, Zhang et al. (2014) described the synthesis of carbon based nanostructured materials using stainless steel as substrate materials, as it can be easily involved in heterogeneous catalysis due to easy separation and recycling. The CNT was multi functionalized using various procedures. Biodiesel conversion of $85 \%$ was obtained with the simultaneous use of the nanocatalyst for $95 \mathrm{~h}$ without losing its structural integrity and morphology (Zhang et al., 2014). Another group (Asri et al., 2020) reported the synthesis of multiwalled CNT loaded with varying $\mathrm{ZnO}$ nanoparticles. The developed heterogeneous solid acid nanocatalysts have been utilized for trans-esterification of Kesambi oil giving methyl esters production of $13.82 \%$ while using only $20 \mathrm{wt} \%$ of $\mathrm{ZnO}$ loaded MWCNT. Carbon nanotubes mainly possess high specific surface area, but its surface area has been reduced greatly upon $\mathrm{ZnO}$ loading. The active sites predominantly increase, ultimately increasing the reaction rate and overall activity of the nanocatalyst, also the mass transfer is greatly reduced (Asri et al., 2020).

Shuit et al. (2015) also reported the use of sulphonated multiwalled carbon nanotubes (s-MWCNT) for esterification of palm fatty acid distillate. The s-MWCNT have shown better catalytic activity in comparison to metal oxide doped CNT with minimum loading of $3 \mathrm{wt} \%$, reaction time and temperature of $2 \mathrm{~h}$ and $170^{\circ} \mathrm{C}$ respectively, yielding methyl esters of $93.5 \%$. The nanocatalysts have been utilized for 5 consecutive runs giving $75 \%$ yield. It can also be easily regenerated with sulphuric acid and further utilized producing a yield of $86.2 \%$. The regeneration process is important in retaining the lost sulphonic group during the leaching process (Shuit and Tan, 2015). Ibrahim et al. (2020) reported the impregnation of sodium oxide over carbon nanotubes for trans-esterification of waste cocking oil. The nanocatalysts have shown excellent catalytic activity due to the presence of sodium ions and oxide ions. The cation imparts lewis acidity while the anion acts as a Brønsted base, thus overall enhancing the catalytic activity with biodiesel production of $97 \%$. It is found to be unstable after 3 cycles because of leaching, which causes deactivation of active sites (Ibrahim et al., 2020).

Carbon nanotubes were also utilized as catalysts, using a homogenous alkali catalyst as reported by Shankar et al. (2017). Biodiesel production from cottonseed oil was evaluated using trans-esterification reaction using homogenous alkalibased carbon nanotubes as a nanocatalyst, giving an optimum yield of 95\% within a time range of 60-120 min (Shankar et al., 2017). Various groups have also used immobilized lipase enzymes over multiwalled carbon nanotubes for biodiesel production as it exhibits enhanced thermal stability and recyclability (Fan et al., 
2017). Fan et al. (2017) reported the synthesis of multiwalled CNT filled with iron oxide further linking with polyamidoamine dendrimers and finally immobilised it over Burkholderia Cepacia Lipase (BCL). The developed catalyst has shown higher catalytic activity due to the presence of large dendrimers linked over to the surface of the nanotubes, giving an ultimate yield of $92.8 \%$, with excellent recyclability up to 20 successive runs along with retaining the activity of catalyst to around $90 \%$. The nanocatalyst can be easily separated due to presence of magnetic iron oxide (Fan et al., 2017). This biotechnological application can be used on a large scale if processed properly, minimizing the large utilization of the nanocatalyst.

Graphene oxide also showed better conversion of fatty acids because of greater surface area and different functional group. Borah et al. (2018) synthesized in situ $\mathrm{TiO}_{2} /$ reduced graphene oxide nanocomposites involving heterogeneous catalysis of waste cooking oil via trans-esterification reaction. The optimized conditions were found to be a methanol to oil molar ratio of $12: 1$ at $65^{\circ} \mathrm{C}$ for $3 \mathrm{~h}$ at a catalyst loading of $1.5 \mathrm{wt} \%$ and corresponds to a conversion efficiency of $98 \%$. The catalyst was dried at $100^{\circ} \mathrm{C}$ for $2 \mathrm{~h}$ and was reused for three cycles with an efficiency of $78.86 \%$ (Borah et al., 2018).

Biochar based nanocatalysts are important in catalyzing the biodiesel production. It is mainly derived from pyrolysis and hydrothermal carbonization of various biomass materials, followed by its functionalization using various materials like metal and metal oxides nanoparticles, sulphonated groups, and nitrogen-containing groups in order to increase its active sites, catalytic activity, porosity, and effective surface area. The other carbon based nanocatalyst can be easily derived from fly ash and sugar-based nanomaterials using the carbonization method, and can be further analyzed for trans- esterification reaction. It was observed that biodiesel production increases, but the catalyst suffers thermal instability and also requires a long reaction time (Abdullah et al., 2017; Gardy et al., 2019b).

Rashid et al. (2019) utilized palm kernel shell as feedstock material for biodiesel production using biochar-based sulphonated zirconium catalyst yielding a fatty acid methyl ester production of $94.3 \%$ using only $3 \mathrm{wt} \%$ catalyst amount at a reaction temperature and time of $75^{\circ} \mathrm{C}$ and $3 \mathrm{~h}$ respectively. The catalyst has also shown successful reusability over five successive cycles with a conversion efficiency of $80 \%$ (Rahman et al., 2018; Rashid et al., 2019).

\section{Zeolite Based Nanocatalyst}

The utilization of zeolite materials has seen upsurge in recent years. They are widely investigated, as they significantly possess specific characteristics like high surface area and thermal stability, presence of active acidic and basic sites (Martínez et al., 2011), high catalytic activity, easily modified structure by using different functionalities, and metal exchange (Zhang et al., 2019). As compared to natural zeolite materials, synthetic-based materials are extensively used on a commercial scale. Their properties can be modified by varying the concentration of silicates and aluminates materials, it can also be predominantly used or modified by using various metal and metal oxide nanoparticles exchange to obtain pure crystalline, uniform pore and particle size materials. It is used as a carrier or support system when impregnated with different nanoparticles of metal oxides like $\mathrm{Fe}_{2} \mathrm{O}_{3}, \mathrm{CaO}, \mathrm{MgO}$, etc. (Go et al., 2007; Centi et al., 2012). Commercially available synthetic zeolites are ZSM-5, $\mathrm{X}, \mathrm{Y}$, and beta zeolites that are mainly used for biodiesel production (Abukhadra et al., 2019). Summary of different zeolites based nanocatalysts involved in biodiesel production are reported in the Table 6.

Xie et al. (2007a) shown the trans-esterification of soybean oil as feedstock using $\mathrm{KOH}$ loaded $\mathrm{NaX}$ zeolite. The obtained optimized reaction conditions were $3 \mathrm{wt} \%$ catalyst amounts, methanol to oil ratio of 10:1, reaction time and temperature of $8 \mathrm{~h}$ and $65^{\circ} \mathrm{C}$ respectively. The biodiesel production was found to be $85.6 \%$ (Xie et al., 2007a). This zeolite was synthesized and analyzed using different compositions of $\mathrm{x}$ and $\mathrm{y}$ for obtaining the maximum yield of biodiesel production. The acidic property of zeolites is due to imbalance in charge present on alumina and silica units, which mainly contribute to the aluminosilicates framework. Overall the uniform pore size and acidity are a considerably important parameter in enhancing the biodiesel (Fattahi et al., 2019; Mohebbi et al., 2020).

Another group has (Pratap et al., 2015) reported the use of $\mathrm{NaY}$ and $\mathrm{KOH} / \mathrm{NaY}$ zeolites catalyst in trans-esterification of Madhuca indica oil. These zeolites have attained a conversion efficiency of $98.9 \%$. As these catalysts are recycled and reused several times, they can be easily activated by washing with methanol followed by calcination in a muffle furnace for a given period of time. Due to the presence of large basic sites, its catalytic activity has increased to a greater extent (Pratap et al., 2015). However, synthesizing nanocatalysts with zeolite plays an important role in achieving maximum conversion, recyclability, and reusability of the catalyst involved in trans-esterification reaction. Trans esterification of soybean oil to biodiesel is carried out using zeolite supported $\mathrm{CaO}$ as strong base catalysts (Wu et al., 2013). Zhuang Li reported the synthesis of $\mathrm{Li} / \mathrm{Na}$ based zeolites, by hydrothermal and micro-emulsion methods and further used for fatty acid methyl production using castor oil as a feedstock material. To obtain the high catalytic activity the synthesized particles were calcined at various calcination temperatures, which is maximally useful for a greater conversion of biodiesel. It was reported that using an optimized catalyst amount of $3 \mathrm{wt} \%$ and an alcohol to oil molar ratio of $18: 1$, biodiesel yield was found to be $98.6 \%$ with reaction temperature and time of $75^{\circ} \mathrm{C}$ and $2 \mathrm{~h}$ respectively. The catalyst has also shown excellent recyclability and reusability (Li et al., 2019).

Martinez et al. described the utilization of $\mathrm{CaO}$ nanoparticles/ $\mathrm{NaX}$ zeolite for trans-esterification of sunflower oil under optimized conditions giving $93.5 \%$ biodiesel production (Martínez et al., 2011). Wu et al. demonstrated $\mathrm{CaO} / \mathrm{NaY}$ zeolites with a conversion efficiency of $95 \%$. However, at certain high temperatures, $\mathrm{CaO}$ may lose its activity due to leaching and instability. To overcome these shortcomings, Firouzjaee and Taghizadeh, 2017 reported the nanomagnetic based zeolite catalyst $\mathrm{CaO} / \mathrm{NaY}-\mathrm{Fe}_{3} \mathrm{O}_{4}$ which shows excellent stability at high temperatures, along with ease in the separation process. Various parameters are being monitored, 
revealing a conversion efficiency of $95.37 \%$ using canola oil as feedstock material (Firouzjaee and Taghizadeh, 2017).

Recently, ZSM based materials have been synthetically modified by the desilication method followed by impregnation to increase the yield of biofuel production. Alaba et al. reported the synthesis of a modified form of ZSM-5 (ZBio) to produce mesoporous zeolites named as 0.3 mesoZBio and 0.4 mesoZBio. In this study, a pyrolysis method was employed to examine the kinetics involved in biodiesel production from shea butter using these catalysts. The analysis was monitored by Thermo-gravimetric analysis. ZBio shows the higher activation energy which is because of the presence of acid active sites producing a large biodiesel production. It may also be confirmed that the direct functional group acidity and porosity are directly related the biodiesel yield of $87 \%$ that was achieved (Vieira et al., 2013; Alaba et al., 2016a). Furthermore, the modification of zeolites with $\mathrm{MoO}_{3}$ nanoparticles was synthesized by a hydrothermal method followed by an impregnation method. The molybdenum impregnation mainly decreases the strength of acid sites and increases the concentration of acidic active sites. The optimized $25 \% \mathrm{MoO} 3$ showed spherical morphology with high crystallinity and mesoporous structure which predominantly increases the conversion process with an efficiency of $98 \%$. The increased catalytic activity is because of high crystallinity and increased acidity. From the given study it can be concluded that functionalization of zeolites with the nanocatalyst will provide a new insight in increasing the production of biodiesel on large scale (Mohebbi et al., 2020).

\section{PHYSICO-CHEMICAL STUDIES OF BIODIESEL PRODUCTION}

Physico-chemical properties test methods for free fatty acids (FFA) content and FAME (fatty acid methyl esters) play a very important role in biofuel production. The biodiesel quality is mainly based on standardized conditions specified by ASTM (American Society for testing Materials), European standard (EN) and Czech Republic (CSN). The quality of biodiesel must meet the given specifications. The properties such as density, kinematic viscosity, oxidation stability, flash point, cloud point, and fire point of the biodiesel produced by utilizing different nanocatalysts were reported and compared with the ASTM (D6751) and EN 14214 standards of biodiesel (Lima et al., 2010 Hoang, 2018; Huang et al., 2020; Lima et al., 2010).These properties are specifically affected by high free fatty acid percentage, water content, and impurities. Estimation of acid value and saponification value of feedstock are also significant as they correspondingly determine the yield and purity of biodiesel.

Abukhadra et al. (2019) have significantly discussed the transesterification reaction under normal stirring and ultrasonic stirring. Interestingly, it shows that the given physico-chemical properties were affected, also the FAME composition differs verily and maximum production of $98.8 \%$ was achieved within a time period of $120 \mathrm{~min}$ (Abukhadra et al., 2019). Trans-esterification reaction involving different nanocatalysts will ultimately produce varieties of FAME compositions. Gardy et al. (2017), Gardy et al. (2018) has analyzed the effect of different nanocatalysts over the same feedstock (waste cooking oil) which produce different compositions of fatty acid methyl esters. For nanocatalyst $\mathrm{TiO}_{2} /$ $\mathrm{PrSO}_{3} \mathrm{H}$, FAME composition includes palmitic acid methyl ester, stearic acid methyl ester, oleic acid methyl ester, linoleic acid methyl ester, linoleic acid methyl ester, and gadoleic acid methyl ester (Gardy et al., 2017), while $\mathrm{SO}_{4} / \mathrm{Fe}-\mathrm{Al}-\mathrm{TiO}_{2}$ nanocatalyst majorly contributes to methyl palmitate, methyl oleate, and methyl linoleate (Gardy et al., 2018). Fatty acid methyl ester compositions produced by using an $\mathrm{Na}_{2} \mathrm{O} / \mathrm{CNT}$ nanocatalyst were found to be myristic acid methyl ester, palmitic acid methyl ester, linoleic acid methyl ester, and oleic acid methyl ester. Major amounts of palmitic and oleic acid were found as it was confirmed by GC analysis. An amount of saturated and unsaturated fatty acid methyl ester (Dantas et al., 2020; Ibrahim et al., 2020) was also reported. The physicochemical studies for various nanocatalysts used in deriving biodiesel have been discussed in Table 8.

\section{Density Measurement}

The density is defined as weight per unit volume, its measurement is important for the mass to volume conversion process required in biofuel production. It has significant impact on fuel quality. Blending of biodiesel fuel and correct formulation of blend are estimated by density measurement (Giakoumis and Sarakatsanis, 2018; NguyenThi et al., 2018). Though density of biodiesel mainly depends on the types of oil used and its treatment process (Pham et al., 2018). It is also affected by molecular weight of the components i.e. fatty acids. High molecular weight corresponds to high density which affects the quality of the fuel. It is significantly reported that low density is better for good quality of fuel (Hoang, 2018). Standard test methods for density measurements are done via pycnomter. The formula for density measurement is given in Eq. 1 (Karmakar et al., 2018).

Density $=\frac{\text { (Mass of pycnometer with biodiesel })-(\text { Mass of empty pycnometer })}{\text { Biodiesel volume }}$

It is determined at temperatures ranging from 15 to $20^{\circ} \mathrm{C}$ depending on the standard specifications (Lima et al., 2010). It reveals information about homogeneity and atomization of the fuel (Ismail and Ali, 2015). Besides experimental determination, theoretical density measurement using optimization software is suitable in finding the correct composition of methyl esters (Pratas et al., 2011). Density can be significantly reduced by the trans-esterification process to achieve the limits of the specified standard.

\section{Study of Kinematic Viscosity}

Viscosity is a substantial parameter as an estimation of the quality of biodiesel. Viscosity indicates the fuel flowing ability as it affects the operation of fuel injection equipment especially at low temperatures (Ong et al., 2020). During the atomization process, high viscosity fuel leads to large droplets formation, thus creating operational problems, increased carbonization eventually leads to increased emission and smoke, while fuel with too low viscosity will results in leakage and increased wear, hence it significantly affects engine performance (Bassam et al., 2019; Huang et al., 2020). Influence of high viscosity of biodiesel 
as compared to diesel fuel leads to concern in process equipment and design. Experimental viscosity measurement is done at a temperature of $40^{\circ} \mathrm{C}$ using a viscometer. The kinematic viscosity of biodiesel as per ASTM D6751 and EN 14214 was given to 1.9-6 and $3.5-5.0 \mathrm{~mm}^{2} / \mathrm{s}$ respectively (Isioma et al., 2013).

Viscosity of biodiesel is primarily dependent on the type of feedstock and treatment it undergoes. FAME derived from edible oil does require less mild conditions to meet the standard of biodiesel as reported by this. While FAME conversion obtained from waste cooking oil possesses high viscosity and requires much treatment (Bikash et al., 2018; Douvartzides et al., 2019). Thus, it is quite tedious to determine viscosity at an experimental level under different reaction conditions in order to obtain optimized parameters. Therefore, it is imperative to approach theoretically the qualitative and quantitative examination of the quality of biodiesel derived from different sources under different reaction conditions. Scientists have used a number of correlation models based on length of carbon chain of methyl esters and degree of unsaturation. Krisnanykura et al. (2006) reported the methyl esters based on coconut oil based on different sets of parameters with maximum deviation of $9.2 \%$. Pinzi et al. (2013) also reported the theoretical approach based on MLR multiple response optimizations for analyzing the degree of unsaturation and length of carbon chain to the obtained biodiesel viscosity.

In order to study and evaluate more than two properties Huang et al. (2020) group have extensively reported the multiple variables such as the effect of fatty acid methyl esters (FAME) composition and temperature over kinematic viscosity according to the following standard EN14103 and ASTM-D 44588 for about 16 biodiesel and 55 FAME -FAME binary blends. The analysis was examined by using two correlation models. Firstly, multiple linear regression (MLR) analysis for kinematic viscosity-composites relationship at $40^{\circ} \mathrm{C}$ while the second correlation was reported between composition-temperature dependent viscosity correlations based on Arrhenius kinetics Chavarria-Hernandez method using viscosity data from Freitas (Hoang, 2018). From the given statistical model, analyzing different kinds of FAME compositions have shown dependency on the viscosity value on temperature which can help in lowering the temperature under optimized conditions.

\section{Determination of Acid Values and lodine Values}

Assessing the acid value is an important parameter as it affects the quality of a particular biodiesel. It is defined as the presence of free acids in the given sample. It can be measured by neutralizing the sample using a specific amount of $\mathrm{KOH}$ as an excess of free fatty acid leads to catalyst deactivation and soap formation. Generally, the acid value of feedstock should range in between 1.86-3.31 mg $\mathrm{KOH} / \mathrm{g}$ oil. However, for waste cooking oil, free fatty acid should be below $4 \mathrm{mg} \mathrm{KOH} / \mathrm{g}$ in order to avoid the pre-treatment process, below this can directly be used for trans esterification reaction (Ismail and Ali, 2015). The biodiesel derived from flaxseed oil has value of $0.186 \pm 0.02 \mathrm{mg} \mathrm{KOH} / \mathrm{g}$, thus falling under the value of the standard method (Ahmad et al., 2019). The acid value is dependent on the type of feedstock used. It was also reported that waste cooking oil shows a high acid value because of thehuge amount of free fatty acid content. High acid value is also responsible for reducing engine performance and causing corrosion. Thus, depending on the content of free fatty acids, reaction conditions needs to be operated in order to maximize the yield.

The iodine value is defined as the measurement of degree of unsaturation. It also depends on the nature and type of feedstock and extremely influences the fuel oxidative ability. The diesel fuel must have an iodine value below $120 \mathrm{~g} \mathrm{I}_{2} / 100 \mathrm{~g}$ of the given sample. It will determine the unsaturation degree in a given mixture of fatty acids. Higher iodine value corresponds to lower oxidative stability. It will also reveal information about sludge formation in fuel, affect lubricant quality, and also cause corrosion (Bassam et al., 2019).

\section{Cetane Number and Saponification Value}

Saponification value is defined as milligrams of $\mathrm{KOH}$ used to saponify $1 \mathrm{~g}$ of fat or oil under a given condition. It is a measure of length and molecular weight of fatty acids. Crude esters have a higher saponification value than oil, and range from 199 to $207 \mathrm{mg} \mathrm{KOH} / \mathrm{g}$ oil (Shalaby, 2013). Longer fatty acids chains have low saponification values as the number of free carboxylic acid groups decrease per unit fat or oil mass. It mainly measures the average molecular weight of the oil or fats present in the given sample. However, the saponification value of biodiesel and crude feedstock does not differ significantly as the average molecular weight undergo small changes. The variation in saponification values are almost similar (Gopinath et al., 2009).

Determination of cetane number is a crucial parameter in quantifying the ignition ability of the fuel. It corresponds to the ability of the fuel to auto ignite quickly after being injected into fuel line, and also shows the ignition quality of the fuel. Higher cetane number corresponds to better ignition quality while low cetane number primarily affects engine parameters with increased emission of smoke, combustion instability, also excessive deposition of unburn materials in engine (Ismail and Ali, 2015). Cetane numbers increase with the increasing length of fatty acids chain. Biodiesel possesses higher cetane numbers as compared to diesel fuel (Adebayo and Ameen, 2011).

\section{Cloud and Pour Point}

Cloud point (CP) is defined as the temperature at which wax crystals become visible when the fuel is cooled. It causes solidification of fuel at lower temperatures which could cause blockage in fuel lines. Cold point is estimated from ASTM Standards D5771, D5772, D5773, and D2500 (Sierra-cantor and Guerrero-fajardo, 2017). A Differential Scanning Calorimetry (DSC) curve can easily examine the formation of crystallization biodiesel (Gardy et al., 2017). Increase in crystallization will eventually cause agglomeration in the fuel thus deteriorating the engine performance. It can also cause blockages in the fuel filters of the engine due to thickening, which eventually ceases the fuel flowability. Easy crystallization of fuel is mainly due to the presence of a high amount of saturated fatty acids.

Pour point is the lowest temperature at which fuel starts flowing. Biodiesel derived from high saturated fatty acid 
content possess a high value of pour point which indicates poor fuel property. The trans-esterification process greatly reduces the value of pour point in order to provide better quality fuel. As high fatty acid content after catalysis shows significant viscosity which also hampers fuel property.

\section{Flash Point}

Flash point is defined as the temperature at which fuel will ignite when exposed to flame. Biodiesel fuels have higher flash points in comparison to petrochemical derived fuels, and hence lead to safe transportation and storage of fuels (Esmaeili et al., 2019; Rasouli and Esmaeili, 2019). Low value of flash point indicates high volatility, it is also helpful in the classification of fuel in order to reduce the risk involved in handling and transportation. Biodiesel's flash point is greater than diesel fuel. The value of biodiesel based on these specification standards EN 14214 and ASTM 6751 must be a minimum of 120 and $130^{\circ} \mathrm{C}$ respectively. It is also easily affected by the presence of impurities like moisture content, unreacted alcohol, and oil content. Thus, it indirectly helps in identifying the quality of biodiesel fuels.

\section{OPTIMIZATION PARAMETERS OF RAW MATERIALS FOR INCREASING BIODIESEL PRODUCTION}

Another important parameter after selecting raw materials based on their physico-chemical properties, is optimizing the reaction conditions for ultimately carrying out the reaction in order to obtain maximum yield, as shown in Figure 4. Earlier optimization was carried out using variation of independent and dependent variables while recording the single response at a time. This maximizes the time consumption along with increasing the chance of ineffectiveness in results as it does not involve the interaction of multiple variables at a time. However, developing new statistical tools and methods would easily process all the running parameters giving significant results (Borah et al., 2019). The reaction parameters were optimized using various software analysis of non-linear techniques like the Taguchi method using MINITAB software, Artificial Neural Network (ANN), Genetic Algorithm (GN), fuzzy logic, design of experiments, and Response Surface Methodology (RSM). In order to increase the biogas yield, ANN and GN are used in the design of experiment and fuzzy logic. These mathematical models are efficient in optimizing multiple reaction parameters at a time. It is also helpful in investigating the reaction kinetics and microbial culture communities which can increase its yield (Kana et al., 2012).

Among these non-linear techniques, RSM is an important tool for investigating the predominant reaction parameters consisting of molasses concentration, initial pH (Hamouda et al., 2015), reaction time and temperature, molar alcohol to oil ratio, and catalyst amount involved in production of bioethanol and biodiesel. Thus, it majorly improves the productivity, reduces time, material, and cost by optimization (Esmaeili et al., 2019).

RSM is an important tool to investigate the variation of different parameters in anaerobic fermentation and catalytic processes, thus improving the productivity of biodiesel by reducing material cost and reaction time by optimization. However in biodiesel production, evaluating the effect of operational parameters like molar ratio, reaction time, temperature and catalyst loading using different types of oil as

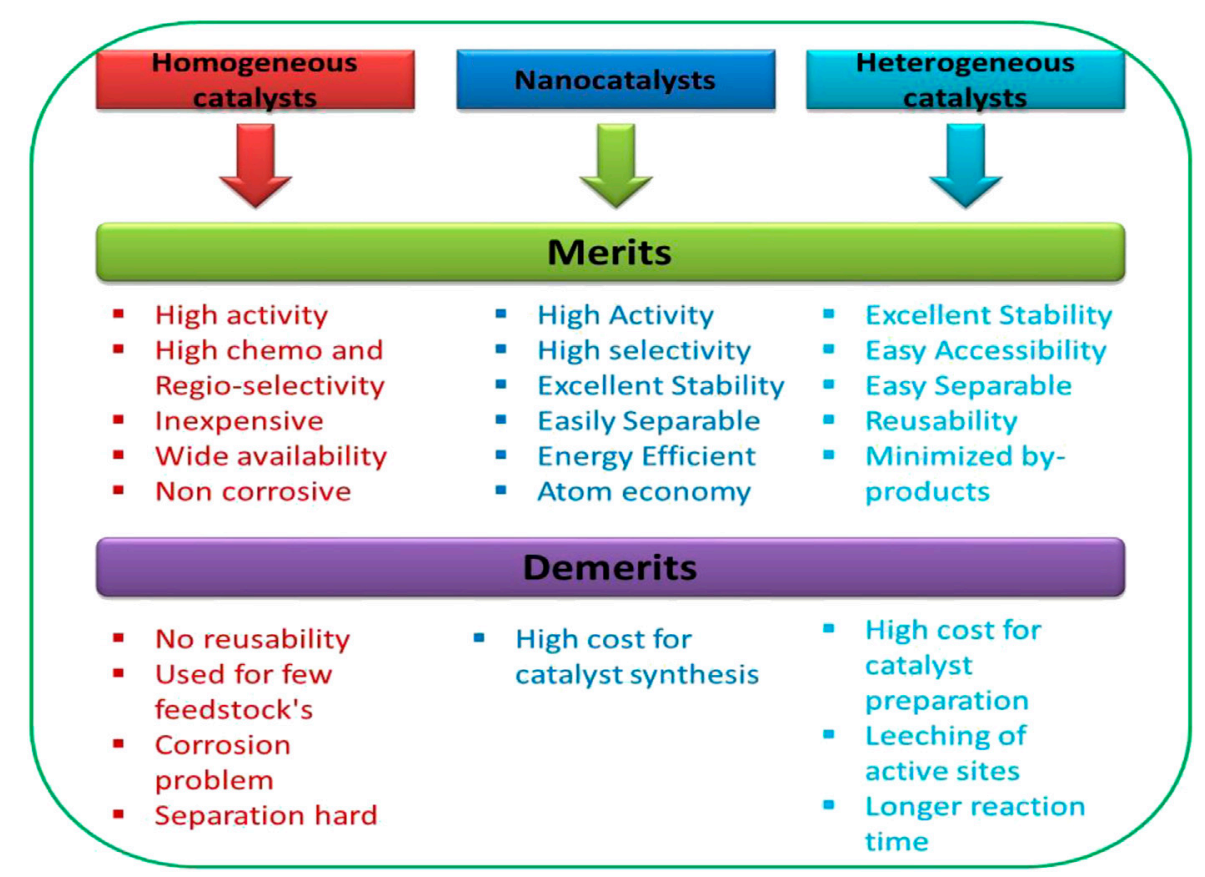

FIGURE 3 | Comparative study of different types of catalysts for biodiesel production. 


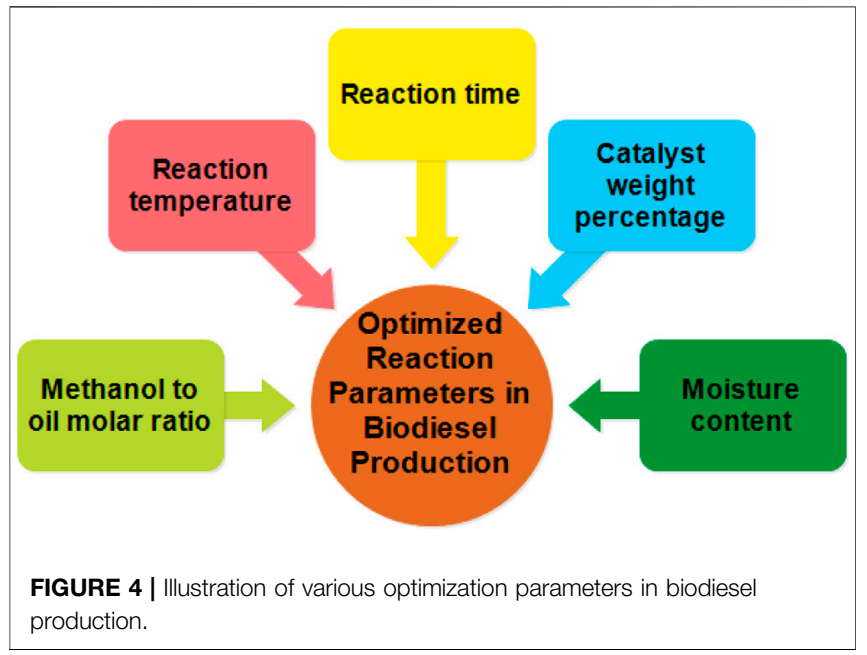

fuel with the help of RSM based experimental design will ultimately increase biofuel production, mainly biodiesel. It is a statistical tool based on mathematical and correlation models accounting for various reaction parameters like molar ratio of alcohol and oil, reaction time and temperature, and catalyst loading concentration. It also requires various other software for analyzing the dependent and independent variables based on regression analysis and analysis of coefficient of variance (ANOVA) in order to optimize and increase the yield of biodiesel. As reported by Ghalandari et al. (2019) transesterification of canola oil to methyl esters (biodiesel) in the presence of the magnetic core-mesoporous shell $\mathrm{KOH} / \mathrm{Fe}_{3} \mathrm{O}_{4} @ \gamma$ $\mathrm{Al}_{2} \mathrm{O}_{3}$ nanocatalyst was investigated using Response Surface Methodology (RSM) based on the Box-Behnken design (BBD) to optimize the influence of important operating variables on the yield of biodiesel. A biodiesel yield of $97.4 \%$ was achieved under optimum reaction conditions with excellent agreement between the predicted and experimental results (Ghalandari et al., 2019). Reaction temperature and free fatty acid content was found to be playing the main role in optimizing the reaction conditions, mainly trans-esterification. Free fatty acids content is found to be predominant in waste cooking oil, as high fatty acid leads to soap formation.

Reducing the concentration by using pre-treatment processes, followed by alkali-based trans-esterification process is an important step in maximizing the yield (Bankovi et al., 2014). It is also imperative that while using methanol as an alcohol source at atmospheric pressure, the temperature should be kept within the boiling point range as reported by many researchers. The esterification process is mainly influenced by the molar ratio of methanol: oil and catalyst concentration due to the impact of the molecular structure on the equilibrium reaction and functional substituents of types of alcohol and acid. However, the conversion rate of oil to methyl ester increases with reaction time, initial mixing and dispersion of methanol makes the reaction slower during $1-5 \mathrm{~min}$, the maximum biodiesel production increases over a $15 \mathrm{~min}$ duration and decreases gradually. Reaction time can be effectively reduced by using various new heating techniques like infra-red and microwave techniques. Important parameters determining the yield of biodiesel production are discussed as follows.

\section{Methanol to Oil Ratio}

The most important factor in biofuel production is the alcohol to oil molar ratio, type of alcohol and triglycerides used. The most probable $\mathrm{M}: \mathrm{O}$ ratio is $3: 1$, as it is beneficial in increasing the solubility of oil and contact time. High molar ratio results in greater conversion of ester within a short span of time (Nanasaheb and Chandrakant, 2012). Stoichiometrically, $3 \mathrm{~mol}$ of alcohol and $1 \mathrm{~mol}$ of triglycerides are required for esterification process in order to yield $3 \mathrm{~mol}$ of fatty acids and $1 \mathrm{~mol}$ of glycerol. High fatty acid content needs a large amount of alcohol in order to proceed with the reaction in the forward direction, as the molar ratio is predominantly dependent on the nature of the oil and catalyst used. Using an optimized amount of alcohol subsequently increases biofuel production. However, using an excess of alcohol will eventually block the active sites of the catalyst and also increase backward reaction more favorably (Gashaw et al., 2015). Various alcohols like methanol, ethanol, propanol, and butanol are mostly used in the trans-esterification process. As reported by many researchers, methanol is mostly used due to low cost, but ethanol can also be used because of its environmentally friendly nature and its production from agricultural waste products (Hossain and Boyce, 2009; Deepalakshmi et al., 2015).

\section{Moisture Content}

While synthesizing biodiesel, trans-esterification is an obvious process as it mainly requires free fatty acid. Moisture content is inevitable with feedstock, and it plays a significant role in deterring the reaction condition due to the formation of soap, ultimately reducing the efficiency of the catalyst, hence reducing the yield of biofuel production. Moisture content also does give different by-products based on the type of catalysis i.e. acid and base catalyzed reaction. Pre-treatment processing of feedstock materials plays an important role in increasing the biofuel production (Gashaw et al., 2015).

\section{Catalyst Weight (Nanocatalyst)}

This is another key factor contributing towards the biodiesel production. The nature and amount of catalyst is mainly dependent on the reaction conditions required i.e. acidic or basic. It is also inadvertently dependent on the nature of feedstock used. If the feedstock is pure with normal moisture and free fatty acid contents, the optimized amount of nanocatalyst is enough in order to carry out the desired reaction. However, if the feedstock has ahigh moisture and free fatty acid content, the occurring trans-esterification process is actually insignificant as it mostly leads to soap formation and decreases the yield of biodiesel production. Considering the latter case, an increased amount of nanocatalyst will certainly increase the biodiesel production. Thus, proper pre-treatment process of feedstock is very important in controlled optimization of the nanocatalyst (Gashaw et al., 2015).

Considering all substantial parameters, the average catalyst amount in most of the study was reported in between $1-6 \mathrm{wt} \%$ for 
optimum amount of the triglycerides content, it also significantly varied depending on the scale of production. However, in some cases it was reported to be high depending on the reaction conditions. Generally high catalyst weight was found to have negative impact on catalytic reaction as it creates mass transfer limitations and reduces the interaction of active sites caused by agglomeration (Kazemifard et al., 2018). Beyond the optimized amount, further addition will decrease production and it is not very effective economically.

\section{Reaction Temperature}

In order to increase the yield, reaction temperature also plays a significant role. An increase in temperature increases the reaction rate and kinetics ultimately reducing the reaction time (Gashaw et al., 2015). The trans-esterification process is usually done below the boiling temperature of alcohol within an optimum temperature range of $50-60^{\circ} \mathrm{C}$ depending on the type of oil used. High temperature mostly corresponds to the evaporation of alcohol used. As reported by many groups, at normal temperature, a $78 \%$ conversion is easily achieved within a 60-90 min time period (Hossain and Boyce, 2009).

\section{Reaction Time}

The temperature and time play a corresponding role in transesterification of oils or fatty acid esters. With an increase in time, fatty acid conversion increases, as initially the conversion is slow due to the dispersion and mixing of oil to methanol or alcohol. As the reaction proceeds towards the threshold, the conversion is usually faster owing to faster reaction kinetics. The nature of the catalyst has a high impact on reaction time as a mixed nanocatalyst requires much less time i.e. $1-2 \mathrm{~h}$. It was reported that within $90 \mathrm{~min}$, maximum ester conversion was achieved, however further increase in time does not increase the yield owing to the reversible nature of reaction, leading to more production of glycerol (Hossain and Boyce, 2009; Gashaw et al., 2015).

As these reaction parameters are being monitored primarily, various groups have reported maximum yield of biofuel production based on these reaction parameters. Since optimization of these parameters is mainly done via following statistics models like RSM and other models, using techniques like ANOVA and BBD configuration in order to find the significance in between these parameters (Anr et al., 2016).
JeyaKumar and Narayanasamy (2019) has reported the use of quadratic model ANOVA using BBD design for initializing the impact between parameters. After fitting in the given model, the most important parameters were found to be reaction time and catalyst loading. However, the variation of other parameters like molar oil ratio and temperature does not yield any significant changes in biofuel production (Jeyakumar and Narayanasamy, 2019). In order to find the significant optimized parameter, all parameters have to be considered first. However, as reported by Lee et al. (2011) based on findings that optimum biodiesel production was obtained at a lower molar ratio of methanol to oil and reaction temperature, $1: 8$ and $55^{\circ} \mathrm{C}$ respectively. It was also observed that increasing methanol concentration increases glycerol solubility, ultimately reducing the yield of final products. Significantly optimized components like a catalyst loading and reaction time of $0.6 \%, 80 \mathrm{~min}$ does contribute greater yields in the biodiesel production while rendering the saponification process. The extremely low and high catalyst loading does not give any significant results. The optimum reaction time of $80 \mathrm{~min}$ was found to be extremely influential in attaining the maximum biodiesel production. From the given observation, it can be inferred that at a given molar ratio, reaction temperature $\left(55^{\circ} \mathrm{C}\right)$ and reaction time $(80 \mathrm{~min})$, the optimized catalyst loading was found to be $0.6 \%$, mainly corroborating that lower catalyst loading gives a maximum yield of $92.43 \%$ (Lee et al., 2011).

Varghese et al. has reported the usage of $0.25 \%$ catalyst loading with other optimum reaction conditions like a reaction time and temperature of $30 \mathrm{~min}$ and $60^{\circ} \mathrm{C}$ respectively with a molar ratio of methanol to oil 6:1 (Ainun et al., 2017). Table 8 briefly summarizes the role of nanocatalysts and the importance of optimization of parameters in enhancing the yield of biodiesel. Other parameters like co-solvent, reactor mixing speed, and type of reactor also show considerable effects on commercialization and large scale production of biodiesel (Chozhavendhan et al., 2020).

\section{CHALLENGES AND LIMITATIONS}

There are various potential challenges faced during the production of biodiesel. Starting from selection of biomass as raw materials in

\begin{tabular}{|c|c|c|c|c|c|c|}
\hline Nanocatalyst & Feedstock & $\begin{array}{c}\text { Catalyst weight } \\
(\%)\end{array}$ & $\begin{array}{l}\text { Specific surface } \\
\text { area }\left(\mathrm{m}^{2} / \mathrm{g}\right)\end{array}$ & $\begin{array}{c}\text { Reaction time } \\
\left.\text { (h)/temp ( }{ }^{\circ} \mathrm{C}\right)\end{array}$ & $\begin{array}{c}\text { Biodiesel yield } \\
(\%)\end{array}$ & References \\
\hline Nano-MgO & Goat fat & 1 & 40.44 & $3 / 70$ & 93.12 & Hassan and Hossein (2019) \\
\hline $\mathrm{MgO} / \mathrm{MgFe}_{2} \mathrm{O}_{4}$ & Sunflower oil & 4 & 97.8 & $4 / 110$ & 91.2 & Alaei et al. (2018) \\
\hline$\gamma-\mathrm{Al}_{2} \mathrm{O}_{3} / \mathrm{KI}$ & Palm oil & 4 & 349 & $4 / 60$ & 98 & Islam et al. (2015) \\
\hline $\mathrm{Ca} / \gamma-\mathrm{Al}_{2} \mathrm{O}_{3}$ & Corn oil & 6 & 6.85 & $5 / 65$ & 87.89 & Moradi et al. (2015) \\
\hline $\mathrm{KOH} / \mathrm{Fe}_{2} \mathrm{O}_{3} / \mathrm{Al}_{2} \mathrm{O}_{3}$ & Canola oil & 4 & 20.46 & $6 / 65$ & 98.8 & Kazemifard et al. (2018) \\
\hline $\mathrm{CaO} @ \mathrm{Fe}_{2} \mathrm{O}_{3}$ & Soyabean oil & 2 & - & $3 / 70$ & 98.8 & Shi et al. (2017) \\
\hline $\mathrm{Na}_{2} \mathrm{SiO}_{3}$ & Animal fat & 0.5 & - & $0.5 / 220$ & 95.6 & Yin et al. (2010) \\
\hline $\mathrm{CaO} / \mathrm{CuFe}_{2} \mathrm{O}_{4}$ & Chicken fat & 3 & - & $4 / 70$ & 94.52 & Seffati et al. (2019) \\
\hline [BsAlm][OTf]@ $\mathrm{SiO}_{2} / \mathrm{CoFe}_{2} \mathrm{O}_{4}$ & Oleic acid & 10 & 364.05 & $12 / 100$ & 87 & Zhen et al. (2012) \\
\hline $\mathrm{Cr} / \mathrm{Ca} / \gamma-\mathrm{Al}_{2} \mathrm{O}_{3}$ & Cooking oil & 6 & 164.32 & 3/65 & 92.79 & Sulaiman et al. (2017) \\
\hline
\end{tabular}


TABLE 5 | Summary of the involvement of carbon-based nanocatalysts in increased biodiesel production.

\begin{tabular}{|c|c|c|c|c|c|c|c|c|}
\hline Nanocatalyst & $\begin{array}{l}\text { Mode } \\
\text { of synthesis }\end{array}$ & Feedstock & $\begin{array}{c}\text { Catalyst } \\
\text { amount } \\
\text { (wt\%) }\end{array}$ & $\begin{array}{l}\text { Methanol } \\
\text { to oil } \\
\text { ratio }\end{array}$ & $\begin{array}{l}\text { Reaction } \\
\text { time } \\
\text { (h) and } \\
\text { reaction } \\
\text { temp. } \\
\text { ('C) }\end{array}$ & $\begin{array}{l}\text { Biodiesel } \\
\text { yield } \\
(\%)\end{array}$ & Recyclability & References \\
\hline $\mathrm{KOH}$ loaded MWCNTs & Impregnation method & Canola oil & 3.02 & $13.56: 1$ & $3.34 / 60$ & 94.23 & 3 & Omraei et al. (2013) \\
\hline $\begin{array}{l}\text { Silicon carbide/sodium hydroxide-graphene oxide (SiC/ } \\
\mathrm{NaOH}-\mathrm{GO})\end{array}$ & In-situ impregnation method & Rapeseed oil oleic acid & 5 & $48: 1$ & $0.1 / 65$ & 96 & 3 & Loy et al. (2019) \\
\hline $\mathrm{Na}_{2} \mathrm{O} / \mathrm{CNT}$ & Impregnation method & Used cooking oil & 3 & $20: 1$ & $3 / 65$ & 97 & 3 & Ibrahim et al. (2020) \\
\hline S-MWCNT & - & Oleic acid & 0.20 & $5.8: 1$ & $1.5 / 135$ & 95.46 & - & Zhang et al. (2009) \\
\hline Sulfonated biochar and activated carbon (AC) & Pyrolysis method & Vegetable oil & $2-8$ & $6: 1$ & $6 / 55-60$ & 97 & 6 & Kastner et al. (2012) \\
\hline
\end{tabular}

TABLE 6 | The summary of zeolite-based nanocatalysts for increased biodiesel production.

\begin{tabular}{|c|c|c|c|c|c|c|c|c|}
\hline Nanocatalyst & $\begin{array}{l}\text { Mode } \\
\text { of synthesis }\end{array}$ & Feedstock & $\begin{array}{c}\text { Catalyst } \\
\text { amount } \\
\text { (wt\%) }\end{array}$ & $\begin{array}{l}\text { Methanol: } \\
\text { oil } \\
\text { ratio }\end{array}$ & $\begin{array}{l}\text { Reaction } \\
\text { time } \\
\text { (h) }\end{array}$ & $\begin{array}{c}\text { Reaction } \\
\text { temperature } \\
\left({ }^{\circ} \mathrm{C}\right)\end{array}$ & $\begin{array}{c}\text { Biodiesel } \\
\text { yield } \\
(\%)\end{array}$ & References \\
\hline Zeolite/chitosan/KOH & - & Waste cooking oil & 1 & $1: 7$ & 3 & $40 \mathrm{~V}(\mathrm{MI})$ & 93 & $\begin{array}{l}\text { Fereidooni and Mehrpooya } \\
\text { (2017) }\end{array}$ \\
\hline Lanthanum-natural zeolite (La/NZA) & Impregnation method & $\begin{array}{l}\text { Crude palm oil } \\
\text { (CPO) }\end{array}$ & 1 & $9: 1$ & 1 & 60 & 85.37 & Setianingsih et al. (2018) \\
\hline ZSM-5 (nanosheets) & Hydrothermal method & Linoleic acid & 10 & $6: 1$ & 4 & 180 & 95.12 & Fawaz et al. (2019) \\
\hline Mesoporous ZSM-5 & Disilication method & Shea butter & 1 & $5: 1$ & $3 \mathrm{~h}$ & 200 & 74.0 & Alaba et al. (2016b) \\
\hline Li/NaY zeolite & $\begin{array}{l}\text { Hydrothermal and microemulsion-assisted co-precipitation } \\
\text { method }\end{array}$ & Castor oil & 3 & $18: 1$ & 2 & 75 & 98.6 & Li et al. (2019) \\
\hline $\begin{array}{l}\text { High silica } \mathrm{MoO}_{3} / \mathrm{B}-\mathrm{ZSM}-5 \\
\text { nanocatalyst }\end{array}$ & $\begin{array}{l}\text { Hydrothermal technique followed by wet impregnation } \\
\text { method }\end{array}$ & WCO & 3 & 2.40 & 6 & 160 & 98 & Mohebbi et al. (2020) \\
\hline
\end{tabular}

Microwave irradiation (MI). 
TABLE 7 | Comparison of the physico-chemical properties of biodiesel derived from different nanocatalysts with standard methods.

\begin{tabular}{|c|c|c|c|c|c|c|c|}
\hline Nanocatalyst & Density $\left(\mathrm{kg} / \mathrm{cm}^{3}\right)$ & Kinematic viscosity $\left(\mathrm{mm}^{2} / \mathrm{s}\right)$ & Flash point $\left({ }^{\circ} \mathrm{C}\right)$ & Acid value $(\mathrm{mgKOH} / \mathrm{g})$ & Water content & Cetane value & References \\
\hline $\mathrm{MgO}$ & 0.866 & - & - & 0.05 & - & - & Amirthavall and (2019) \\
\hline Zn doped $\mathrm{CaO}$ nanocatalyst & 0.873 & 3.7 & 142 & 0.15 & - & - & Borah et al. (2019) \\
\hline $\mathrm{TiO}_{2} / \mathrm{PrSO}_{3} \mathrm{H}$ & 0.898 & 4.8 & 171 & 0.41 & - & - & Gardy et al. (2017) \\
\hline $\mathrm{TiO}_{2}-0.5 \mathrm{C}_{4} \mathrm{H}_{5} \mathrm{KO}_{6}$ catalyst & 0.891 & 3.5 & 173 & - & - & 57 & Ambat et al. (2018a) \\
\hline Synthetic B/ZP catalyst & 0.872 & 3.84 & 178.5 & 0.041 & & 53.7 & Abukhadra et al. (2019) \\
\hline ASTM D6751 & $0.82-0.90\left(20^{\circ} \mathrm{C}\right)$ & - & $>130$ & $<0.8$ & $<0.05$ & $>47$ & - \\
\hline EN14214 & $0.86-0.90\left(15^{\circ} \mathrm{C}\right)$ & - & $>120$ & $<0.5$ & $<0.05$ & $>41$ & - \\
\hline
\end{tabular}

TABLE 8 | Summary of nanocatalysts and optimization parameters used in production of biodiesel.

\begin{tabular}{|c|c|c|c|c|c|c|c|c|}
\hline Nanocatalyst & $\begin{array}{c}\text { Mode } \\
\text { of synthesis }\end{array}$ & Feedstock & $\begin{array}{c}\text { Alcohol } \\
\text { to oil } \\
\text { molar } \\
\text { ratio }\end{array}$ & $\begin{array}{c}\text { Catalyst } \\
\text { amount } \\
(w t \%)\end{array}$ & $\begin{array}{l}\text { Reaction } \\
\text { time }\end{array}$ & $\begin{array}{l}\text { Reaction } \\
\text { temp }\end{array}$ & $\begin{array}{c}\text { Biodiesel } \\
\text { yield } \\
(\%)\end{array}$ & References \\
\hline $\mathrm{SO}_{4} / \mathrm{Mg}-\mathrm{Al}-\mathrm{Fe}_{3} \mathrm{O}_{4}$ catalyst & Co-precipitation & WCO & $9: 1$ & 4.0 & $300 \mathrm{~min}$ & $95^{\circ} \mathrm{C}$ & 98.5 & Gardy et al. (2019a) \\
\hline MgO nanoparticles & Sol-gel & Waste cooking oil & $10: 1$ & 2 & $2 \mathrm{~h}$ & $60^{\circ} \mathrm{C}$ & 80 & Amirthavalli and Warrier (2019) \\
\hline CuO-CaO catalyst & Sol-gel & Moringa oleifera oil & $0.3: 1$ & 4 & $150 \mathrm{~min}$ & $65^{\circ} \mathrm{C}$ & 95.24 & Nomura et al. (2019) \\
\hline $\mathrm{CaO}$ nanoparticles & Thermal decomposition & WCO oil & $8: 1$ & 1 & $90 \mathrm{~min}$ & $50^{\circ} \mathrm{C}$ & 96 & Anbessie et al. (2019) \\
\hline $\begin{array}{l}\mathrm{KOH} / \mathrm{Ca}_{12} \mathrm{Al}_{14} \mathrm{O}_{33} \\
\text { nanocatalyst }\end{array}$ & Combustion method & Canola oil & $12: 1$ & 4 & $60 \mathrm{~min}$ & $450 \mathrm{WMl}$ & 83.5 & Nayebzadeh et al. (2017) \\
\hline $\mathrm{KF} / \mathrm{CaO}-\mathrm{Fe}_{3} \mathrm{O}_{4}$ & Impreg nation method & Stillingia oil & $12: 1$ & 4 & $3 \mathrm{~h}$ & $65^{\circ} \mathrm{C}$ & 95 & Hu et al. (2011) \\
\hline$(\mathrm{MgO})$ catalysts & Co-precipitation method & Waste cooking oil using & $24: 1$ & 2 & $1 \mathrm{~h}$ & $65^{\circ} \mathrm{C}$ & 93.3 & John et al. (2018) \\
\hline$(\mathrm{KOH})$ & - & Coconut oil & $6: 1$ & 1.0 & $60 \mathrm{~min}$ & $70^{\circ} \mathrm{C}$ & 97.20 & Samuel et al. (2016) \\
\hline $\mathrm{CaO}$ derived from egg shell & $\begin{array}{l}\text { Calcination-hydration-dehydration } \\
\text { as }\end{array}$ & Scenedesmus armatus & $10: 1$ & 1.61 & $4 \mathrm{~h}$ & $75^{\circ} \mathrm{C}$ & 90.44 & Pandit and Fulekar (2019) \\
\hline MgO- $\mathrm{La}_{2} \mathrm{O}_{3}$ nanocatalysts & Co-precipitation method & Sunflower oil & $18: 1$ & 3 & $5 \mathrm{~h}$ & $65^{\circ} \mathrm{C}$ & 97.7 & Feyzi et al. (2017) \\
\hline $\mathrm{Sr}_{3} \mathrm{Al}_{2} \mathrm{O}_{6}$ & Sol-gel & Soybean oil & $25: 1$ & 1.3 & $61 \mathrm{~min}$ & $60^{\circ} \mathrm{C}$ & 95.7 & Rashtizadeh et al. (2014) \\
\hline Au@Ag core-shell NPs & Deposition method & Sunflower oil & $5: 1$ & 5 & $2.0 \mathrm{~h}$ & $65^{\circ} \mathrm{C}$ & 86.9 & Baneriee et al. (2014) \\
\hline $\mathrm{K}_{2} \mathrm{CO}_{3} / \mathrm{Al}_{2} \mathrm{O}_{3}$ & Impregnation method & Sunflower oil & $12: 1$ & 5 & $4 \mathrm{~h}$ & $80^{\circ} \mathrm{C}$ & 99.3 & Silveira et al. (2019) \\
\hline
\end{tabular}

Microwave irradiation (MI). 
order to obtain free fatty acids that are used as feedstock material. Transforming biomass is a prerequisite task so as to minimize the obstacles caused later in the production of biodiesel. Biomass obtained from edible materials has a limited production as it mainly contributes to derived food. As deforestation and problematic issues of fossil fuel derived products has plagued its zenith, large scale plantation of non-edible plants in order to retrieve oil is an important and main concern. Another stage is the technological development required in extraction of oils from feedstock. Each and every stage in biofuel production is energy intensive and needs to be properly optimized. Furthermore, different types of nanocatalysts can be investigated depending on the morphology and size of nanoparticles which also play a pivotal role in maximizing the yield of biofuel, as structural and catalytic stability of nanocatalysts at high temperatures is also a major issue and concern in augmenting the overall productivity of biofuel. So fabrication and modification of nanocatalysts of high surface to volume ratio, catalytic stability, and high catalytic activity is significant in optimizing the parameters of biodiesel production while maintaining an environmental-friendly approach to minimize chemical based pollution during nanocatalyst synthesis.

\section{CONCLUSION}

Biodiesel production plays a prominent role in alleviating the utilization of energy generation from fossil derived products. Despite lower energy production in comparison to fossil fuels, the novel designing of nanocatalysts, producing microbial cultures and developing optimization techniques are succinctly helpful in expanding the large-scale production of biodiesel.

In this review the detailed discussion on biodiesel production via trans-esterification reaction has been presented. The role of nanocatalysts in heterogeneous catalysis has been analyzed on the basis of its type and vastness. The metal oxides based nanocatalysts are attributed with the exceptional properties of large surface area to volume ratio, different morphology and high activity as well as selectivity of the catalyst. Nanomagnetic and mixed metal oxide based nanocatalyst have played a substantial role in enhancing specific surface area, pore size and average pore diameter. Using innumerable functionalized groups, significant modification of nanocatalysts can be achieved which ultimately increase the overall acidity, reduces the leaching of active metals and creates more active acidic and basic sites for the catalytic reaction. Inevitably, advancement in nanotechnology significantly limits the use of fossil fuels and also mitigates the pollution level. However, the biodiesel production still faces some major challenges like identifying feedstock, as a concerning task corresponding to biofuel production, mainly biodiesel. Biodiesel derived from edible oils are posing certain restrictions relating to cost and food related issues. In comparison to this, non-edible oils and classes of microalgae show better prospects in regard to esterification process of free fatty acids. As pre-treatment of the feedstock is a necessary step in minimizing the formation of side-reactions and the saponification process, it mostly hinders the production of biodiesel by affecting its physico-chemical properties thus reducing the overall quality of biodiesel. Monitoring optimization of reaction parameters and physico-chemical properties are imperatively significant in increasing biodiesel production. Using optimum amounts of nanocatalyst, reaction parameters like methanol to oil ratio, catalyst weight, reaction temperature and time can be significantly improved, thus overall increasing the quality and quantity of biodiesel.

\section{FUTURE OUTLOOK}

In light of the review, future studies can be significantly made in the following directions to overcome the existing limitations regarding biodiesel production:

Devising a plan for large-scale usability of non-edible feedstock oils and exploration in increasing the production of algae based biomass which possess major content of oil.

Developing nanocatalysts possessing multi-functionality active sites, which concomitantly minimize the effect of leaching and can also withstand disintegration during the trans-esterification reaction.

Functionalization of carbonaceous and zeolite-based catalysts using nanomaterials and polymeric materials for increasing its catalytic activity, specificity, and stability.

Exploiting structural modification based on morphology and size of the nano-based materials so as to enhance the reaction kinetics involved in biodiesel production.

Evolving statistical tools for effective optimization of reaction conditions on a large scale.

Finally, technological advancement is necessary in establishing the reaction process on a large scale to minimize the masstransfer resistance, extensive energy usage, and utilization of by-products. Thereby increasing the scope in maintaining the optimized reaction conditions, and hence increasing the biodiesel production.

\section{AUTHOR CONTRIBUTIONS}

$\mathrm{SB}, \mathrm{SaS}$ and AG have contributed to outlining the structure and writing of the manuscript. MK and SuS have reviewed the manuscript thoroughly.

\section{ACKNOWLEDGMENTS}

Authors are sincerely thankful to Aligarh Muslim University for providing necessary research facilities. Authors are highly grateful to the financial support in the form of DRS II grant given by UGC and FIST, PURSE grants of the DST. 


\section{REFERENCES}

Abdullah, S. H. Y. S., Hanapi, N. H. M., Azid, A., Umar, R., Juahir, H., Khatoon, H., et al. (2017). A review of biomass-derived heterogeneous catalyst for a sustainable biodiesel production. Renew. Sustain. Energy Rev. 70, 1040-1051. doi:10.1016/j.rser.2016.12.008

Abukhadra, M. R., Ibrahim, S. M., Yakout, S. M., El-zaidy, M. E., and Abdeltawab, A. A. (2019). Synthesis of $\mathrm{Na}^{+}$trapped bentonite/zeolite-P composite as a novel catalyst for effective production of biodiesel from palm oil; E ff ect of ultrasonic irradiation and mechanism. Energy Convers. Manag. 196, 739-750. doi:10. 1016/j.enconman.2019.06.027

Achten, W. M. J., Verchot, L., Franken, Y. J., Mathijs, E., Singh, V. P., Aerts, R., et al. (2008). Jatropha bio-diesel production and use. Biomass Bioenergy 32, 1063-1084. doi:10.1016/j.biombioe.2008.03.003

Adebayo, G. B., and Ameen, M. O. (2011). Physico-chemical properties of biodiesel produced from Jatropha Curcas oil. J. Microbiol. Biotechnol. Res., 1 (1), 12-16.

Ahmad, T., Danish, M., Kale, P., Geremew, B., Adeloju, S. B., Nizami, M., et al. (2019). Optimization of process variables for biodiesel production by transesterification of flaxseed oil and produced biodiesel characterizations. Renew. Energy, 139, 1272-1280. doi:10.1016/j.renene.2019.03.036

Ainun, H., Bhargavi, G., Rao, P. N., and Lutero, D. S. (2017). "Ultrasonication assisted production of biodiesel from sunflower oil by using $\mathrm{CuO}: \mathrm{Mg}$ heterogeneous nanocatalyst," in IOP Conference Series: Materials Science and Engineering, 1-7. doi:10.1088/1757-899X/225/1/012213

Akia, M., Yazdani, F., Motaee, E., Han, D., and Arandiyan, H. (2014). A review on conversion of biomass to biofuel by nanocatalysts. Biofuel Res. J. 1, 16-25. doi:10.18331/BRJ2015.1.1.5

Alaba, A. P., Sani, Y. M., Mohd, W., and Daud, W. M. W. A. (2016a). A comparative study on thermal decomposition behavior of biodiesel samples produced from shea butter over micro- and mesoporous ZSM-5 zeolites using different kinetic models. J. Therm. Anal. Calorim. 126 (2), 943-948. doi:10. 1007/s10973-016-5505-8

Alaba, P. A., Sani, M. Y., Mohammad, Y. I., Abakr, A. Y., and Daud, W. M. W. A. (2016b). Synthesis and application of hierarchical mesoporous HZSM-5 for biodiesel production from shea butter. J. Taiwan Inst. Chem. Eng. 59, 405-412. doi:10.1016/j.jtice.2015.09.006

Alaei, S., Haghighi, M., Toghiani, J., and Rahmani Vahid, B. (2018). Magnetic and reusable $\mathrm{MgO} / \mathrm{MgFe}_{2} \mathrm{O}_{4}$ nanocatalyst for biodiesel production from sunflower oil: influence of fuel ratio in combustion synthesis on catalytic properties and performance. Ind. Crops Prod. 117, 322-332. doi:10.1016/j. indcrop.2018.03.015

Ali, J., Fathollah, P., and Akbar, M. (2020). Recent advances of biodiesel production using ionic liquids supported on nanoporous materials as catalysts: a Review. Fr. En. Res. 8, 144. doi:10.3389/fenrg.2020.00144

Ambat, I., Srivastava, V., Haapaniemi, E., and Sillanpää, M. (2018a). Application of potassium ion impregnated titanium dioxide as nanocatalyst for transesterification of linseed oil. Energy and Fuels 32 (11), 11645-11655. doi:10.1021/acs.energyfuels.8b03310

Ambat, I., Srivastava, V., and Sillanpää, M. (2018b). Recent advancement in biodiesel production methodologies using various feedstock: a review. Renew. Sustain. Energy Rev. 90, 356-369. doi:10.1016/j.rser.2018.03.069

Amirthavalli, V., and Warrier, A. R. (2019). Production of biodiesel from waste cooking oil using MgO nanocatalyst. AIP Conf. Proc. 2115, 030609. 10.1063/1. 5113448

Anbessie, T., Mamo, T. T., and Mekonnen, Y. S. (2019). Optimized biodiesel production from waste cooking oil (WCO) using calcium oxide $(\mathrm{CaO})$ nanocatalyst. Sci. Rep. 9, 18982. doi:10.1038/s41598-019-55403-4

Anr, R., Saleh, A. A., Islam, S., Hamdan, S., and Maleque, A. (2016). Biodiesel production from crude jatropha oil using a highly active heterogeneous nanocatalyst by optimizing transesterification reaction parameters. Energy Fuels 30, 334-343. doi:10.1021/acs.energyfuels. 5b01899

Anwer, A. H., Khan, M. D., Khan, N., Nizami, A. S., Rehan, M., and Khan, M. Z. (2019). Development of novel $\mathrm{MnO}_{2}$ coated carbon felt cathode for microbial electroreduction of $\mathrm{CO}_{2}$ to biofuels. J. Environ. Manag. 249, 109376. doi:10. 1016/j.jenvman.2019.109376
Asri, N. P., Yuniati, Y., Hindarso, H., Supraptoand Yogaswara, R. R. (2020). "Biodiesel production from Kesambi (Schleichera oleosa) oil using multi-walled carbon nanotubes supported zinc oxide as a solid acid catalyst," in IOP Conference Series: Earth and Environmental Science, 1-9. doi:10.1088/1755$1315 / 456 / 1 / 012003$

Azhar, S. M. H., Abdulla, R., Jambo, S. A., Marbawi, H., Azlan, J., Azifa, A., et al. (2017). Yeasts in sustainable bioethanol production: a review. Biochem. Biophys. Rep. 10, 52-61. doi:10.1016/j.bbrep.2017.03.003

Azyan, N., Adila, F., Sulaiman, S., and Jamal, P. (2018). Thermally produced nano catalyst for biodiesel production: a review. J. Adv. Res. Fluid Mech. Therm. Sci. 2 (2), 139-147.

Balat, M. (2011). Potential alternatives to edible oils for biodiesel production-a review of current work. Energy Convers. Manag. 52 (2), 1479-1492. doi:10. 1016/j.enconman.2010.10.011

Banerjee, M., Dey, B., Talukdar, J., and Chandra, M. (2014). Production of biodiesel from sun flower oil using highly catalytic bimetallic gold - silver core - shell nanoparticle. Energy 69, 695-699. doi:10.1016/j.energy.2014.03.065

Bankovi, I. B., Stojkovi, I. J., Stamenkovi, O. S., and Veljkovic, V. B. (2014). Waste animal fats as feedstocks for biodiesel production. Renew. Sustain. Energy Rev. 32, 238-254. doi:10.1016/j.rser.2014.01.038

Bassam, A., Abatal, M., Tzuc, O. M., Pedro, L. C. S., and Aguilar-uc, C. (2019). Physical and chemical properties of biodiesel obtained from amazon Sailfin Catfish (Pterygoplichthys pardalis) biomass oil. J. Chem. 2019, 7829630. doi:10. 1155/2019/7829630

Behzadi, S., and Farid, M. M. (2007). Review: examining the use of different feedstock for the production of biodiesel. Asia-Pac. J. Chem. Eng. 2, 480-486. doi:10.1002/apj

Bharti, P., and Singh, B. (2019). Process optimization of biodiesel production catalyzed by $\mathrm{CaO}$ nanocatalyst using response surface methodology. J. Nanostruct. Chem. 9 (4), 269-280. doi:10.1007/s40097-019-00317-w

Bikash, B., Choudhury, N. D., and Bora, D. K. (2018). "Physicochemical assessment of Pumpkin (Cucurbita pepo L.) seed oil as a viable feedstock for biodiesel production oil extraction, "in Conference proceedings of the second international conference on recent advances in bioenergy research (Newyork, NY, Springer).

Borah, J. M., Das, A., Das, V., Bhuyan, N., and Deka, D. (2019). Transesteri fi cation of waste cooking oil for biodiesel production catalyzed by $\mathrm{Zn}$ substituted waste egg shell derived CaO nanocatalyst. Fuel 242, 345-354. doi:10.1016/j.fuel.2019. 01.060

Borah, J. M., Devi, A., Abha, R., Deka, D., Guan, Q., Li, Y., et al. (2018). Biodiesel production from waste cooking oil catalyzed by in-situ decorated $\mathrm{TiO}_{2}$ on reduced graphene oxide nanocomposite.CATCOM 2012 (3), 7250-7258. doi:10. $1155 / 2012 / 542426$

Centi, G., Perez-pariente, J., and Roth, W. J. (2012). Zeolite-based materials for novel catalytic applications: opportunities, perspectives and open problems. Catal. Today 179, 2-15. doi:10.1016/j.cattod.2011.10.006

Chavan, S. B., Kumbhar, R. R., Madhu, D., Singh, B., and Sharma, Y. C. (2015). Synthesis of biodiesel from Jatropha curcas oil using waste eggshell and study of its fuel properties. RSC Adv. 5, 63596-63604. doi:10.1039/c5ra06937h

Chen, H., and Fu, X. (2016). Industrial technologies for bioethanol production from lignocellulosic biomass. Renew. Sustain. Energy Rev. 57, 468-478. doi:10. 1016/j.rser.2015.12.069

Chouhan, A. P. S., and Sarma, A. K. (2011). Modern heterogeneous catalysts for biodiesel production: a comprehensive review. Renew. Sust. Energ. Rev. 15, 4378-4399. doi:10.1016/j.rser.2011.07.112

Chozhavendhan, S., Vijay Pradhap Singh, M., Fransila, B., Praveen Kumar, R., and Karthiga Devi, G. (2020). A review on influencing parameters of biodiesel production and purification processes. Current Res. Green Sust. Chem. 1-2, 1-6. doi:10.1016/j.crgsc.2020.04.002

Clohessy, J., and Kwapinski, W. (2020). Carbon-based catalysts for biodiesel production-a review. Appl. Sci. 10, 918. doi:10.3390/app10030918

Dai, Y. M., Lin, J. H., Huang, S. T., Lee, W. L. W., Hsieh, C. H., Chen, F. H., et al. (2020). Natural soil and lithium carbonate as economical solid-base catalysts for biodiesel production. Energy Rep. 6, 2743-2750. doi:10.1016/j.egyr.2020.09.041

Dantas, J., Leal, E., Cornejo, D. R., Kiminami, R. H. G. A., and Costa, A. C. F. M. (2020). Biodiesel production evaluating the use and reuse of synthesized in pilot-scale. Arabian J. Chem. 13 (1), 3026-3042. doi:10.1016/j.arabjc.2018.08. 012 
Deepalakshmi, S., Sivalingam, A., Thirumarimurugan, M., and Sivakumar, P. (2015). Environmental effects optimization of biodiesel synthesis from Calophyllum inophyllum. Energy Sources, Part A Recovery, Util. Environ. Eff. 37 (00), 2601-2608. doi:10.1080/15567036.2015.1007403

Deepanraj, B., and Senthilkumar, N. (2020). Biogas from food waste through anaerobic digestion: optimization with response surface methodology. Biomass Convers. Biorefin., 85-96.

Deepanraj, B., Sivasubramanian, V., and Jayaraj, S. (2016). Multi-response optimization of process parameters in biogas production from food waste using Taguchi - Grey relational analysis. Energy Convers. Manag. 141, 429-438. doi:10.1016/j.enconman.2016.12.013

Douvartzides, S. L., Charisiou, N. D., Papageridis, K. N., and Goula, M. A. (2019). Green diesel: biomass feedstocks, production technologies, catalytic research, fuel properties and performance in compression ignition internal combustion engines. Energies 12, 809. doi:10.3390/en12050809

El-seesy, A. I., Abdel-rahman, A. K., Bady, M., and Ookawara, S. (2016). The influence of multi-walled carbon nanotubes additives into non-edible biodieseldiesel fuel blend on diesel engine performance and emissions. Energy Procedia. 100 166-172. doi:10.1016/j.egypro.2016.10.160

Esmaeili, H., Yeganeh, G., and Esmaeilzadeh, F. (2019). Optimization of biodiesel production from Moringa oleifera seeds oil in the presence of nano - $\mathrm{MgO}$ using Taguchi method. Int. Nano Lett. 9 (3), 257-263. doi:10.1007/s40089-019-0278-2

Faisal, A., Priji, P., Unni, P., Nair, K., and Kulangara, M. (2018). Optimization of parameters for the production of biodiesel from rubber seed oil using onsite lipase by response surface methodology. 3 Biotech. 8 (11), 459. doi:10.1007/ s13205-018-1477-7

Fan, Y., Su, F., Li, K., Ke, C., and Yan, Y. (2017). Carbon nanotube filled with magnetic iron oxide and modified with polyamidoamine dendrimers for immobilizing lipase toward application in biodiesel production. Sci. Rep. 7 , 45643. doi:10.1038/srep 45643

Fattah, I. M. R., Ong, H. C., Mahlia, T. M. I., Mofijur, M., and Silitonga, A. S. (2020). State of the art of catalysts for biodiesel production. Front. Energy Res. 8, 101. doi:10.3389/fenrg.2020.00101

Fattahi, N., Triantafyllidis, K., Luque, R., and Ramazani, A. (2019). Zeolite-based catalysts: a valuable approach toward. Catalysts 9, 758. doi:10.3390/ catal9090758

Fawaz, E. G., Salam, D. A., Pinard, L., and Daou, T. J. (2019). Catalysis science \& technology crystal morphologies of HZSM-5 zeolites for the catalyst effectiveness $\dagger$. Catal. Sci. Technol. 9, 5456-5471. doi:10.1039/c9cy01427f

Fereidooni, L., and Mehrpooya, M. (2017). Experimental assessment of electrolysis method in production of biodiesel from waste cooking oil using zeolite/chitosan catalyst with a focus on waste biorefinery. Energy Convers. Manag. 147, 145-154. doi:10.1016/j.enconman.2017.05.051

Feyzi, M., Hassankhani, A., and Rafiee, H. R. (2013). Preparation and characterization of $\mathrm{Cs} / \mathrm{Al} / \mathrm{Fe}_{3} \mathrm{O}_{4}$ nanocatalysts for biodiesel production. Energy Convers. Manag. 71, 62-68. doi:10.1016/j.enconman.2013.03.022

Feyzi, M., Hosseini, N., Yaghobi, N., and Ezzati, R. (2017). Preparation, characterization, kinetic and thermodynamic studies of $\mathrm{MgO}-\mathrm{La}_{2} \mathrm{O}_{3}$ nanocatalysts for biodiesel production from sunflower oil. Chem. Phys. Lett. 677, 19-29. doi:10.1016/j.cplett.2017.03.014

Gardy, J., Hassanpour, A., Lai, X., Ahmed, M. H., and Rehan, M. (2017). Applied catalysis $\mathrm{B}$ : environmental biodiesel production from used cooking oil using a novel surface functionalised $\mathrm{TiO}_{2}$ nano-catalyst. Appl. Catal. B Environ. 207, 297-310. doi:10.1016/j.apcatb.2017.01.080

Gardy, J., Nourafkan, E., Osatiashtiani, A., Lee, A. F., and Wilson, K. (2019a). Applied catalysis B: environmental a core-shell $\mathrm{SO}_{4} / \mathrm{Mg}-\mathrm{Al}-\mathrm{Fe}_{3} \mathrm{O}_{4}$ catalyst for biodiesel production. Appl. Catal. B Environ. 259, 118093. doi:10.1016/j.apcatb. 2019.118093

Gardy, J., Osatiashtiani, A., Céspedes, O., Hassanpour, A., Lai, X., Lee, A. F., et al. (2018). Applied Catalysis B: environmental A magnetically separable $\mathrm{SO}_{4} / \mathrm{Fe}-\mathrm{Al}-\mathrm{TiO}_{2}$ solid acid catalyst for biodiesel production from waste cooking oil. Appl. Catal. B Environ. 234, 268-278. doi:10.1016/j.apcatb. 2018.04.046

Gardy, J., Rehan, M., Hassanpour, A., Lai, X., and Nizami, A. (2019b). Advances in nano-catalysts based biodiesel production from non-food feedstocks. J. Environ. Manag. 249, 109316. doi:10.1016/j.jenvman.2019.109316

Gashaw, A., Getachew, T., and Abile, T. (2015). A review on biodiesel production as alternative fuel. J. For. Prod. Ind. 4 (2), 80-85.
Ghalandari, A., Taghizadeh, M., and Rahmani, M. (2019). Statistical optimization of the biodiesel production process using a magnetic core-mesoporous shell $\mathrm{KOH} / \mathrm{Fe}_{3} \mathrm{O}_{4} @ \mathrm{~g}-\mathrm{Al}_{2} \mathrm{O}_{3}$ nanocatalyst. Chem. Eng. Technol. 42 (1), 89-99. doi:10.1002/ceat.201700658

Giakoumis, E. G., and Sarakatsanis, C. K. (2018). Estimation of biodiesel cetane number, density, kinematic viscosity and heating values from its fatty acid weight composition. Fuel 222, 574-585. doi:10.1016/j.fuel.2018.02.187

Go, J. M., Romero, M. D., Ovejero, G., Uguina, M. A., and Rodrı, A. (2007). Fast tailoring of the acid - base properties in the NaX zeolite by cesium-exchange under microwave heating. Microporous Mesoporous Mater. 98, 317-322. doi:10. 1016/j.micromeso.2006.09.024

Gog, A., Roman, M., Tosa, M., Paizs, C., and Irimie, F. D. (2012). Biodiesel production using enzymatic transesterification - current state and perspectives. Renew. Energy 39, 10-16. doi:10.1016/j.renene.2011.08.007

Gopinath, A., Puhan, S., and Nagarajan, G. (2009). Theoretical modeling of iodine value and saponification value of biodiesel fuels from their fatty acid composition. Renew. Energy 34 (7), 1806-1811. doi:10.1016/j.renene.2008.11. 023

Guan, Q., Li, Y., Chen, Y., Shi, Y., Gu, J., Li, B., et al. (2017). Biodiesel production through triglycerides transesterification. RSC Adv. 7, 7250-7258. doi:10.1039/ c6ra28067f

Firouzjaee, M. H., and Taghizadeh, M. (2017). Optimization of process variables for biodiesel production using the. Chem. Eng. Technol. 40 (6), 1140-1148. doi:10.1002/ceat.201600406

Hamouda, H. I., Nassar, H. N., Madian, H. R., Amr, S. S. A., and El-gendy, N. S. (2015). Response surface optimization of bioethanol production from sugarcane molasses by pichia veronae Strain HSC-22. Biotechnol. Res. Internat. 2015, 905792. 10.1155/2015/905792

Hassan, R., and Hossein, E. (2019). Characterization of $\mathrm{MgO}$ nanocatalysts to produce biodiesel from goat fat using trans-esterification process. Biotech. 9, 429. doi:10.1007/s13205-019-1963-6

Hoang, A. T. (2018). Prediction of the density and viscosity of biodiesel and the influence of biodiesel properties on a diesel engine fuel supply system. J. Mar. Eng. Technol. 4177, 1-13. doi:10.1080/20464177.2018.1532734

Hossain, A. B. M. S., and Boyce, A. N. (2009). Biodiesel production from waste sunflower cooking oil as an environmental recycling process. Bulg. J. Agric. Sci. 15 (4), 312-317.

Hossain, N., Mahlia, T. M. I., and Saidur, R. (2019a). Biotechnology for biofuels latest development in microalgae - biofuel production with nano - additives. Biotechnol. Biofuels 12, 125. doi:10.1186/s13068-019-1465-0

$\mathrm{Hu}, \mathrm{S}$., Guan, Y., Wang, Y., and Han, H. (2011). Nano-magnetic catalyst KF/CaO $\mathrm{Fe}_{3} \mathrm{O}_{4}$ for biodiesel production. Appl. Energy 88 (8), 2685-2690. doi:10.1016/j. apenergy.2011.02.012

Huang, Y., Li, F., Bao, G., Wang, W., and Wang, H. (2020). Estimation of kinematic viscosity of biodiesel fuels from fatty acid methyl ester composition and temperature. J. Chem. Eng. Data 65, 2476-2485. doi:10.1021/acs.jced. $9 \mathrm{~b} 01127$

Ibrahim, M. L., Adlina Nik Abdul Khalil, N. N., Islam, A., Rashid, U., Ibrahim, S. F., Mashuri, S. I. S., et al. (2020). Preparation of $\mathrm{Na}_{2} \mathrm{O}$ supported CNTs nanocatalyst for e ffi cient biodiesel production from waste-oil. Energy Convers. Manag. 205, 112445. doi:10.1016/j.enconman.2019.112445

Isioma, N., Muhammad, Y., Sylvester, O. D., Innocent, D., and Linus, O. (2013). Cold flow properties and kinematic viscosity of biodiesel. Univ. J. Chem. 1 (4), 135-141. doi:10.13189/ujc.2013.010402

Islam, A., Taufiq-Yap, Y. H., Ravindra, P., Teo, S. H., Sivasangar, S., and Chan, E.-S. (2015). Biodiesel synthesis over $\gamma$-Al2O3/KI catalyst. Energy 89, 965-973. doi:10.1016/j.energy.2015.06.036

Ismail, S. A. A., and Ali, R. F. M. (2015). Physico-chemical properties of biodiesel manufactured from waste frying oil using domestic adsorbents. Sci. Technol. Adv. Mater. 16 (3), 034602. doi:10.1088/1468-6996/16/3/034602

Jeyakumar, N., and Narayanasamy, B. (2019). Environmental effects optimization of used cooking oil methyl ester production using response surface methodology. Energy Sources, Part A Recov., Util. Environ. Eff. 41 (19), 2313-2325. doi:10.1080/15567036.2018.1555633

John, A. A. L., Judith, K. J., and Udaya, V. (2018). Optimization of biodiesel production from waste cooking oil by magnesium oxide nanocatalyst synthesized using coprecipitation method. Clean Technol. Environ. Policy 20 (6), 1219-1231. doi:10.1007/s10098-018-1547-x 
Kana, E. B. G., Oloke, J. K., Lateef, A., and Adesiyan, M. O. (2012). Modeling and optimization of biogas production on saw dust and other co-substrates using artificial neural network and genetic algorithm. Renew. Energy 46, 276-281. doi:10.1016/j.renene.2012.03.027

Karmakar, R., Kundu, K., and Rajor, A. (2018). Fuel properties and emission characteristics of biodiesel produced from unused algae grown in India. Petrol. Sci. 15 (2), 385-395. doi:10.1007/s12182-017-0209-7

Kastner, J. R., Miller, J., Geller, D. P., Locklin, J., Keith, L. H., and Johnson, T. (2012). Catalytic esterification of fatty acids using solid acid catalysts generated from biochar and activated carbon. Catal. Today 190 (1), 122-132. doi:10.1016/ j.cattod.2012.02.006

Kazemifard, S., Nayebzadeh, H., Saghatoleslami, N., and Safakish, E. (2018). Assessment the activity of magnetic $\mathrm{KOH} / \mathrm{Fe}_{3} \mathrm{O}_{4} @ \mathrm{Al}_{2} \mathrm{O}_{3}$ core-shell nanocatalyst in transesterification reaction: effect of $\mathrm{Fe} / \mathrm{Al}$ ratio on structural and performance. Environ. Sci. Pollut. Res. 25, 32811-32821. doi:10.1007/ s11356-018-3249-7

Khan, O., Yadav, A. K., Khan, M. E., and Parvez, M. (2019). Characterization of bioethanol obtained from Eichhornia Crassipes plant; its emission and performance analysis on CI engine. Energy Sources, Part A: recovery, Util., Environ. Eff., 1-11. doi:10.1080/15567036.2019.1648600

Kovács, K. L., Ács, N., Kovács, E., Wirth, R., Rákhely, G., Strang, O., et al. (2013). Improvement of biogas production by bioaugmentation. BioMed Res. Internat. 2013, 482653. 10.1155/2013/482653

Krisnangkura, K., Yimsuwan, T., and Pairintra, R. (2006). An empirical approach in predicting biodiesel viscosity at various temperatures. Fuel 85, 107-113. doi:10.1016/j.fuel.2005.05.010

Kushwaha, D., Upadhyay, S. N., and Mishra, P. K. (2018). "Nanotechnology in bioethanol/biobutanol production nanotechnology in bioethanol/biobutanol production," in Nanotechnology for biofuel production. biofuel and biorefinery technologies (Cham, Switzerland: Springer International Publishing). doi:10. 1007/978-3-319-75052-1

Le Quynh, H., Vestergaard, M. C., and Tamiya, E. (2017). Carbon-based nanomaterials in biomass-based fuel-fed fuel cells. Sensors 17, 2587. doi:10. 3390/s17112587

Lee, H. V., Yunus, R., Juan, J. C., and Tau, Y. H. (2011). Process optimization design for jatropha-based biodiesel production using response surface methodology. Fuel Process. Technol. 92, 2420-2428. doi:10.1016/j.fuproc. 2011.08.018

Li, P., He, C., Li, G., Ding, P., Lan, M., and Gao, Z. (2020). Biological pretreatment of corn straw for enhancing degradation efficiency and biogas production. Bioengineered 11 (1), 251-260. doi:10.1080/21655979.2020.1733733

Li, Z., Ding, S., Chen, C., Qu, S., Du, L., Lu, J., et al. (2019). Recyclable Li/NaY zeolite as a heterogeneous alkaline catalyst for biodiesel production: process optimization and kinetics study. Energy Convers. Manag. 192, 335-345. doi:10. 1016/j.enconman.2019.04.053

Lima, L. S., Barbosa, T. P., da Silva, L. F. B., Santo Filho, D. M. E., Castro, C. S. C., Dos Santos, J. J. P., Jr., et al. (2010). Biodiesel density characterization using a pycnometer. Simposio de Metrología, 1-8.

Loy, A. C. M., Quitain, A. T., Lam, K. M., Yusup, S., Sasaki, M., and Kida, T. (2019). Development of high microwave-absorptive bifunctional graphene oxide-based catalyst for biodiesel production. Energy Convers. Manag. 180, 1013-1025. doi:10.1016/j.enconman.2018.11.043

Mardhiah, H. H., Ong, H. C., Masjuki, H. H., Lim, S., and Lee, H. V. (2017). A review on latest developments and future prospects of heterogeneous catalyst in biodiesel production from non-edible oils. Renew. Sust. Energ. Rev. 67, 1225-1236. doi:10.1016/j.rser.2016.09.036

Martchamadol, J., and Kumar, S. (2012). Thailand's energy security indicators. Renew. Sustain. Energy Rev. 16 (8), 6103-6122. doi:10.1016/j.rser.2012.06.021

Martínez, S. L., Romero, R., Romero, A., Víctor, S., and Natividad, R. (2011). Preparation and characterization of $\mathrm{CaO}$ nanoparticles/ $\mathrm{NaX}$ zeolite catalysts for the transesterification of sunflower oil. Ind. Eng. Chem. Res. 50, 2665-2670. doi:10.1021/ie1006867

Marwaha, A., Dhir, A., Mahla, S. K., and Mohapatra, S. K. (2018). An overview of solid base heterogeneous catalysts for biodiesel production. Catal. Rev. 60 (4), 594-628. doi:10.1080/01614940.2018.1494782

Mguni, L. L., Meijboom, R., and Jalama, K. (2012). Biodiesel production over nano$\mathrm{MgO}$ supported on titania. Internat. J. Mat. Metall. Eng. 6 (4), 380-384.
Mishra, V. K., and Goswami, R. (2017). A review of production , properties and advantages of biodiesel. Biofuels 1-17. doi:10.1080/17597269.2017.1336350

Mohebbi, S., Rostamizadeh, M., and Kahforoushan, D. (2020). Effect of molybdenum promoter on performance of high silica $\mathrm{MoO}_{3} / \mathrm{B}-\mathrm{ZSM}-5$ nanocatalyst in biodiesel production. Fuel 266, 1-8. doi:10.1016/j.fuel.2020. 117063

Moradi, G., Mohadesi, M., Rezaei, R., and Moradi, R. (2015). Biodiesel production using $\mathrm{CaO} / \gamma-\mathrm{Al}_{2} \mathrm{O}_{3}$ catalyst synthesized by sol-gel method. Canad. J. Chem.Eng. 93, 1531-1538. doi:10.1002/cjce.22258

Nanasaheb, D. S., and Chandrakant, M. K. (2012). Preparation of methyl esters from thespesia populnea 1 . oil and its engine exhausts studies thespesia populnea l. oil and its engine. Int. J. Green Energy 9, 130-138. doi:10.1080/ 15435075.2011.621495

Nayebzadeh, H., Saghatoleslami, N., Haghighi, M., and Tabasizadeh, M. (2017). $\mathrm{KOH} / \mathrm{Ca} 12 \mathrm{Al} 14 \mathrm{O} 33$ nanocatalyst for biodiesel production via microwave. J. Taiwan Inst. Chem. Eng. 1-8. doi:10.1016/j.jtice.2017.03.018

NguyenThi, T. X., Bazile, J. P., and Bessières, D. (2018). Density measurements of waste cooking oil biodiesel and diesel blends over extended pressure. Energies 11, 1212. doi:10.3390/en 11051212

Nizami, A., and Rehan, M. (2018). Towards nanotechnology-based biofuel industry. Biofuel Res. J., 18, 798-799. doi:10.18331/BRJ2018.5.2.2

Nomura, K., Terwilliger, P., Niju, S., Raj, F. R., Anushya, C., and Balajii, M. (2019). Optimization of acid catalyzed esterification and mixed metal oxide catalyzed transesterification for biodiesel production from Moringa oleifera oil, Green Process. Synth. 8, 756-775. doi:10.1515/gps-2019-0045

Omraei, M., Sheibani, S., Sadrameli, S. M., and Tow, J. (2013). Preparation of biodiesel using KOH-MWCNT catalysts: an optimization study. Ind. Eng. Chem. Res. 52, 1829-1835. doi:10.1021/ie301418y

Ong, H. C., Mofiju, M., Silitonga, A. S., Gumilang, D., Kusumo, F., and Mahlia, T. M. I. (2020). Physicochemical properties of biodiesel synthesised from Grape seed, Philippine tung, Kesambi, and palm oils. Energies 13, 1319. doi:10.3390/ en13061319

Pan, H., Li, H., Zhang, H., Wang, A., Jin, D., and Yang, S. (2018). Effective production of biodiesel from non-edible oil using facile synthesis of imidazolium salts-based BrØnsted-Lewis solid acid and co-solvent. Energy Convers. Manag. 166, 534-544. doi:10.1016/j.enconman.2018.04.061

Pan, H., Li, H., Zhang, H., Wang, A., and Yang, S. (2019). Acidic ionic liquidfunctionalized mesoporous melamine-formaldehyde polymer as heterogeneous catalyst for biodiesel production. Fuel 239, 886-895. doi:10.1016/j.fuel.2018.11. 093

Pan, H., Liu, Y., Xia, Q., Zhang, H., Guo, L., Li, H., et al. (2020). Synergetic combination of a mesoporous polymeric acid and a base enables highly efficient heterogeneous catalytic one-pot conversion of crude: jatropha oil into biodiesel. Green Chem. 22 (5), 1698-1709. doi:10.1039/c9gc04135d

Pandit, P. R., and Fulekar, M. H. (2019). Biodiesel production from Scenedesmus armatus using egg shell waste as nanocatalyst. Mater. Today: Proc. 10, 75-86. doi:10.1016/j.matpr.2019.02.191

Pérez, A., Casas, A., Fernández, C. M., Ramos, M. J., and Rodríguez, L. (2010). Winterization of peanut biodiesel to improve the cold flow properties. Bioresour. Technol. 101 (19), 7375-7381. doi:10.1016/j.biortech.2010.04.063

Pham, M. T., Hoang, A. T., Anh, T. L., Rahman, A., Al Tawaha, A. R. M., and Le, V. V. (2018). Measurement and prediction of the density and viscosity of biodiesel blends. Internat. J. Technol. 9, 1015. doi:10.14716/ijtech.v9i5.1950

Pinzi, S., Leiva-candia, D., López-garcía, I., Redel-macías, M. D., and Dorado, M. P. (2013). Latest trends in feedstocks for biodiesel production. Biofuels, Bioprod. Bioref. 8, 126-143. doi:10.1002/bbb.1435

Poonjarernsilp, C., Sano, N., and Tamon, H. (2014). Applied catalysis B: environmental Hydrothermally sulfonated single-walled carbon nanohorns for use as solid catalysts in biodiesel production by esterification of palmitic acid. Appl. Catal. B Environ. 147, 726-732. doi:10.1016/j.apcatb.2013.10.006

Pratap, S. R., Shamshuddin, S. Z. M., Thimmaraju, N., Shyamsundar, M., and Reena, S. S. (2015). Kinetics of transesterification of Madhuca Indica oil over modified zeolites: biodiesel synthesis. Bangladesh J. Sci. Ind. Res. 50 (4), 271-278. doi:10.3329/bjsir.v50i4.25836

Pratas, M. J., Freitas, S. V. D., Oliveira, M. B., Monteiro, S. C., and Lima, S. (2011). Biodiesel density: experimental measurements and prediction models. Energy Fuels 25, 2333-2340. doi:10.1021/ef2002124 
Prokopowicz, A., Zaciera, M., Sobczak, A., Bielaczyc, P., and Woodburn, J. (2015). The effects of neat biodiesel and biodiesel and hvo blends in diesel fuel on exhaust emissions from a light duty vehicle with a diesel engine. Environ. Sci. Technol. 49, 7473-7482. doi:10.1021/acs.est.5b00648

Rahman, W. U., Fatima, A., Anwer, A. H., Athar, M., Khan, M. Z., Khan, N. A., et al. (2018). Biodiesel synthesis from eucalyptus oil by utilizing waste egg shell derived calcium based metal oxide catalyst. Process Saf. Environ. Protect. 122, 1-35. doi:10.1016/j.psep.2018.12.015

Rai, M., César, J., Soler, M. F., Ricardo, P., Marcelino, F., Brumano, L. P., et al. (2016). Strategic role of nanotechnology for production of bioethanol and biodiesel. Nanotechnol. Rev. 5 (2), 231-250. doi:10.1515/ntrev-2015-0069

Rashid, U., Soltani, S., Shean, T., Choong, Y., and Nehdi, I. A. (2019). Palm biochar-based sulphated zirconium (Zr-AC-HSO3) catalyst for methyl ester production from palm fatty acid distillate. Catalysts 9, 1029. doi:10.3390/ catal9121029

Rashtizadeh, E., Farzaneh, F., and Talebpour, Z. (2014). Bioresource technology synthesis and characterization of $\mathrm{Sr}_{3} \mathrm{Al}_{2} \mathrm{O}_{6}$ nanocomposite as catalyst for biodiesel production. Bioresour. Technol. 154, 32-37. doi:10.1016/j.biortech.2013.12.014

Rasouli, H., and Esmaeili, H. (2019). Characterization of $\mathrm{MgO}$ nanocatalyst to produce biodiesel from goat fat using transesterification process. 3 Biotech 9, 429. doi:10.1007/s13205-019-1963-6

Rengasamy, M., Anbalagan, K., Mohanraj, S., and Pugalenthi, V. (2014). Biodiesel production from Pongamia pinnata oil using synthesized iron nanocatalyst. Internat. J. ChemTech Res. 6 (10), 4511-4516.

Roy, T., Sahani, S., Madhu, D., and Chandra Sharma, Y. (2020). A clean approach of biodiesel production from waste cooking oil by using single phase $\mathrm{BaSnO}_{3}$ as solid base catalyst: mechanism, kinetics \& E-study. J. Clean. Prod. 265, 121440. doi:10.1016/j.jclepro.2020.121440

Ruhul, A. M., Kalam, M. A., Masjuki, H. H., Fattah, I. M. R., Reham, S. S., and Rashed, M. M. (2015). State of the art of biodiesel production processes: a review of the heterogeneous catalyst. RSC Adv. 5, 101023-101044. doi:10.1039/ C5RA09862A

Samuel, O. D., Giwa, S. O., and El-, A. (2016). Optimization of coconut oil ethyl esters reaction variables and prediction model of its blends with diesel fuel for density and kinematic viscosity model. Biofuels 7269, 1-11. doi:10.1080/ 17597269.2016 .1192445

Saoud, K. (2018). Nanocatalyst for biofuel production: a review. New York, NY: Springer International Publishing. doi:10.1007/978-3-319-75052-1

Sarno, M., and Iuliano, M. (2019). Biodiesel production from waste cooking oil. Green Process. Synth. 8, 828-836.

Seffati, K., Honarvar, B., Esmaeili, H., and Esfandiari, N. (2019). Enhanced biodiesel production from chicken fat using $\mathrm{CaO} / \mathrm{CuFe}_{2} \mathrm{O}_{4}$ nanocatalyst and its combination with diesel to improve fuel properties. Fuel 235, 1238-1244. doi:10.1016/j.fuel.2018.08.118

Senés-Guerrero, C., Contreras, A. C., Lobo, J. F., BenitoTinoco, P., SillerCepeda, J. H., and Pacheco, A. (2019). Biogas - producing microbial composition of an anaerobic digester and associated bovine residues. MicrobiologyOpen 8, 854. doi:10.1002/mbo3.854

Setianingsih, A., Wisrayetti, K., and Bahri, S. (2018). "Effect of Lanthanum-Natural Zeolite , La/NZA catalyst on biodiesel production from crude palm oil," in IOP conference series: materials science and engineering, 11. doi:10.1088/1757-899X/ $345 / 1 / 012007$

Shalaby, E. A. (2013). Biofuel: sources , extraction and determination. doi:10.5772/ 51943

Shankar, A. A., Pentapati, P. R., and Prasad, R. K. (2017). Biodiesel synthesis from cottonseed oil using homogeneous alkali catalyst and using heterogeneous multi walled carbon nanotubes: characterization and blending studies. Egyptian J. Petrol. 26 (1), 125-133. doi:10.1016/j.ejpe.2016.04.001

Shi, M., Zhang, P., Fan, M., and Jiang, P. (2017). Influence of crystal of $\mathrm{Fe}_{2} \mathrm{O}_{3}$ in magnetism and activity of nanoparticle $\mathrm{CaO} @ \mathrm{Fe}_{2} \mathrm{O}_{3}$ for biodiesel production. Fuel 197, 343-347. doi:10.1016/j.fuel.2017.02.060

Shu, Q., Zhang, Q., Xu, G., and Wang, J. (2009). Preparation of biodiesel using s-MWCNT catalysts and the coupling of reaction and separation. Food Bioprod. Process. 87, 164-170. doi:10.1016/j.fbp.2009.01.004

Shuit, S. H., and Tan, S. H. (2015). Biodiesel production via esterification of palm fatty acid distillate using sulphonated multi-walled carbon nanotubes as a solid acid catalyst: process study, catalyst reusability and kinetic study. Bioenerg. Res. 8, 605-617. doi:10.1007/s12155-014-9545-2
Shuit, S. H., Ng, E. P., and Tan, H. S. (2015). A facile and acid-free approach towards the preparation of sulphonated multi-walled carbon nanotubes as a strong protonic acid catalyst for biodiesel production. J. Taiwan Inst. Chem. Eng. 1-9. doi:10.1016/j.jtice.2015.02.018

Sierra-cantor, J. F., and Guerrero-fajardo, C. A. (2017). Methods for improving the cold fl ow properties of biodiesel with high saturated fatty acids content: a review. Renew. Sustain. Energy Rev. 72, 774-790. doi:10.1016/j.rser.2017. 01.077

Silveira, E. G., Haber, V., Reyero, I., and Serrano-lotina, A. (2019). Biodiesel production from heterogeneous catalysts based $\mathrm{K}_{2} \mathrm{CO}_{3}$ supported on extruded $\gamma-\mathrm{Al}_{2} \mathrm{O}_{3}$. Fuel 241, 311-318. doi:10.1016/j.fuel.2018.12.074

Singh, A., and Gaurav, K. (2018). Advancement in catalysts for transesterification in the production of Biodiesel: a review. J Biochem Tech 9 (1), 17-27.

Srivastava, N., Srivastava, M., Gupta, V. K., Manikanta, A., Mishra, K., Singh, S., et al. (2018). Recent development on sustainable biodiesel production using sewage sludge. 3 Biotech. 8 (5), 1-11. doi:10.1007/s13205-018-1264-5

Sulaiman, N. F., Azelee, W., Abu, W., Toemen, S., Kamal, N. M., and Nadarajan, R. (2019). In depth investigation of bi-functional, $\mathrm{Cu} / \mathrm{Zn} / \mathrm{g}-\mathrm{Al}_{2} \mathrm{O}_{3}$ catalyst in biodiesel production from low-grade cooking oil: optimization using response surface methodology. Renew. Energy 135, 408-416. doi:10.1016/j.renene.2018. 11.111

Sulaiman, N. F., Wan Abu Bakar, W. A., and Ali, R. (2017). Response surface methodology for the optimum production of biodiesel over $\mathrm{Cr} / \mathrm{Ca} / \gamma-\mathrm{Al}_{2} \mathrm{O}_{3}$ catalyst: catalytic performance and physicochemical studies. Renew. Energy 113, 697-705. doi:10.1016/j.renene.2017.06.007

Talebian-kiakalaieh, A., Aishah, N., Amin, S., and Mazaheri, H. (2013). A review on novel processes of biodiesel production from waste cooking oil. Appl. Energy 104, 683-710. doi:10.1016/j.apenergy.2012.11.061

Thangaraj, B., Solomon, P. R., Muniyandi, B., Ranganathan, S., and Lin, L. (2019). Catalysis in biodiesel production - a review. Clean Energy 3 (1), 2-23. doi:10. 1093/ce/zky020

Todorović, Z. B., Troter, D. Z., Đokić-stojanović, D. R., and Veličković, A. V. (2019). Optimization of CaO-catalyzed sunflower oil methanolysis with crude biodiesel as a cosolvent. Fuel, 23, 903-910. doi:10.1016/j.fuel.2018. 10.056

Touqeer, T., Mumtaz, M. W., Mukhtar, H., Irfan, A., Akram, S., Shabbir, A., et al. (2020). Fe3O4-PDA-lipase as surface functionalized nano biocatalyst for the production of biodiesel using waste cooking oil as feedstock: characterization and process optimization. Energies 13, 177. doi:10.3390/ en 13010177

Vahid, B. R., and Haghighi, M. (2016). Urea-nitrate combustion synthesis of $\mathrm{MgO} /$

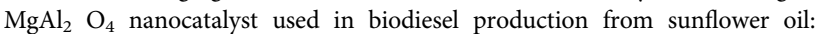
influence of fuel ratio on catalytic properties and performance. Energy Convers. Manag. 126, 362-372. doi:10.1016/j.enconman.2016.07.050

Veronica Winoto, N. Y. (2019). Optimization of biodiesel production using nanomagnetic $\mathrm{CaO}$-based catalysts with subcritical methanol transesterification of rubber seed oil. Energies 12, 230. doi:10.3390/ en 12020230

Vieira, S. S., Magriotis, Z. M., Santos, N. A. V., Saczk, A. A., Hori, C. E., and Arroyo, P. A. (2013). Bioresource Technology Biodiesel production by free fatty acid esterification using lanthanum $\left(\mathrm{La}^{3+}\right)$ and HZSM-5 based catalysts. Bioresour. Technol. 133, 248-255. doi:10.1016/j.biortech.2013.01.107

Wen, Z., Yu, X., Tu, S., Yan, J., and Dahlquist, E. (2010). Synthesis of biodiesel from vegetable oil with methanol catalyzed by Li-doped magnesium oxide catalysts. Appl. Energy 87 (3), 743-748. doi:10.1016/j.apenergy.2009.09.013

Wu, H., Zhang, J., Wei, Q., Zheng, J., and Zhang, J. (2013). Transesterification of soybean oil to biodiesel using zeolite supported $\mathrm{CaO}$ as strong base catalysts. Fuel Process. Technol. 109, 13-18. doi:10.1016/j.fuproc.2012.09. 032

Xie, W., Huang, X., and Li, H. (2007a). Soybean oil methyl esters preparation using $\mathrm{NaX}$ zeolites loaded with $\mathrm{KOH}$ as a heterogeneous catalyst. Bioresour. Technol. 98, 936-939. doi:10.1016/j.biortech.2006.04.003

Xie, W., Yang, Z., and Chun, H. (2007b). Catalytic properties of lithium-doped zno catalysts used for biodiesel preparations. Ind. Eng. Chem. Res. 46, 7942-7949. doi:10.1021/ie070597s

Yin, J. Z., Ma, Z., Hu, D. P., Xiu, Z. L., and Wang, T. H. (2010). Biodiesel production from subcritical methanol transesterfication of soyabean oil with sodium silicate. Energy Fuel. 24, 3179-3182 
Youse, S., Haghighi, M., and Vahid, B. R. (2019). Role of glycine/nitrates ratio on structural and texture evolution of $\mathrm{MgO}$-based nanocatalyst fabricated by hybrid microwave-impregnation method for biofuel production. Energy Convers. Manag. 182, 251-261. doi:10.1016/j.enconman.2018.12.067

Zahan, K. A., and Kano, M. (2018). Biodiesel production from palm oil, its byproducts, and mill effluent: a review. Energies 11 (8), 1-25. doi:10.3390/ en11082132

Zhang, D., Wei, D., Li, Q., Ge, X., Guo, X., Xie, Z., et al. (2014). High performance catalytic distillation using CNTs-based holistic catalyst for production of high quality biodiesel. Sci. Rep. 4, 4021. doi:10.1038/srep04021

Zhang, X. L., Yan, S., Tyagi, R. D., and Surampalli, R. Y. (2013). Biodiesel production from heterotrophic microalgae through transesteri fi cation and nanotechnology application in the production. Renew. Sustain. Energy Rev. 26, 216-223. doi:10.1016/j.rser.2013.05.061

Zhang, Z., Yuan, X., Miao, S., Li, H., Shan, W., and Jia, M. (2019). Effect of Fe additives on the catalytic performance of Ion-exchanged CsX zeolites for sidechain Alkylation of Toluene with methanol. Catalysts 9, 829. doi:10.3390/ catal9100829
Zhen, B., Jiao, Q., Zhang, Y., Wu, Q., and Li, H. (2012). Acidic ionic liquid immobilized on magnetic mesoporous silica: preparation and catalytic performance in esterification. Appl. Catal. A General 445-446, 239-245. doi:10.1016/j.apcata.2012.08.023

Zuliani, A., Ivars, F., and Luque, R. (2018). Advances in nanocatalyst design for biofuel production. ChemCatChem, 10, 1968-1981. doi:10.1002/cctc.201701712

Conflict of Interest: The authors declare that the research was conducted in the absence of any commercial or financial relationships that could be construed as a potential conflict of interest.

Copyright (c) 2020 Bano, Ganie, Sultana, Sabir and Khan. This is an open-access article distributed under the terms of the Creative Commons Attribution License (CC $B Y)$. The use, distribution or reproduction in other forums is permitted, provided the original author(s) and the copyright owner(s) are credited and that the original publication in this journal is cited, in accordance with accepted academic practice. No use, distribution or reproduction is permitted which does not comply with these terms. 